\title{
Geophysical and geochemical controls on the megafaunal community of a high Arctic cold seep
}

\author{
Arunima Sen ${ }^{1}$, Emmelie K. L. Åström ${ }^{1}$, Wei-Li Hong ${ }^{1,2}$, Alexey Portnov ${ }^{1,3}$, Malin Waage ${ }^{1}$, Pavel Serov ${ }^{1}$, \\ Michael L. Carroll ${ }^{1,4}$, and JoLynn Carroll ${ }^{4}$ \\ ${ }^{1}$ Centre for Arctic Gas Hydrate, Environment and Climate (CAGE), Department of Geosciences, \\ UiT The Arctic University of Norway, Troms $\varnothing, 9037$, Norway \\ ${ }^{2}$ Geological Survey of Norway (NGU), Trondheim, 7491, Norway \\ ${ }^{3}$ School of Earth Sciences, Ohio State University, Columbus, Ohio, 43210, USA \\ ${ }^{4}$ Akvaplan-niva, FRAM - High North Research Centre for Climate and the Environment, Troms $\varnothing, 9296$, Norway
}

Correspondence: Arunima Sen (arunima.sen@uit.no)

Received: 15 December 2017 - Discussion started: 11 January 2018

Revised: 5 July 2018 - Accepted: 6 July 2018 - Published: 25 July 2018

\begin{abstract}
Cold-seep megafaunal communities around gas hydrate mounds (pingos) in the western Barents Sea $\left(76^{\circ} \mathrm{N}, 16^{\circ} \mathrm{E}, \sim 400 \mathrm{~m}\right.$ depth) were investigated with highresolution, geographically referenced images acquired with an ROV and towed camera. Four pingos associated with seabed methane release hosted diverse biological communities of mainly nonseep (background) species including commercially important fish and crustaceans, as well as a species new to this area (the snow crab Chionoecetes opilio). We attribute the presence of most benthic community members to habitat heterogeneity and the occurrence of hard substrates (methane-derived authigenic carbonates), particularly the most abundant phyla (Cnidaria and Porifera), though food availability and exposure to a diverse microbial community is also important for certain taxa. Only one chemosynthesis-based species was confirmed, the siboglinid frenulate polychaete Oligobrachia cf. haakonmosbiensis. Overall, the pingo communities formed two distinct clusters, distinguished by the presence or absence of frenulate aggregations. Methane gas advection through sediments was low, below the single pingo that lacked frenulate aggregations, while seismic profiles indicated abundant gas-saturated sediment below the other frenulate-colonized pingos. The absence of frenulate aggregations could not be explained by sediment sulfide concentrations, despite these worms likely containing sulfide-oxidizing symbionts. We propose that high levels of seafloor methane seepage linked to subsurface gas reservoirs support an abundant and active
\end{abstract}

sediment methanotrophic community that maintains high sulfide fluxes and serves as a carbon source for frenulate worms. The pingo currently lacking a large subsurface gas source and lower methane concentrations likely has lower sulfide flux rates and limited amounts of carbon, insufficient to support large populations of frenulates. Two previously undocumented behaviors were visible through the images: grazing activity of snow crabs on bacterial mats, and seafloor crawling of Nothria conchylega onuphid polychaetes.

\section{Introduction}

Cold seeps, where hydrocarbons and reduced gases emerge from the seafloor, are ubiquitous in the world's oceans and despite being discovered only a few decades ago (Paull et al., 1984), they have been studied intensively in a variety of settings around the world (Levin, 2005; Levin et al., 2016; Sibuet and Olu, 1998; Sibuet and Olu-Le Roy, 2002). However, cold seeps in the Arctic Ocean have received less attention and the literature on Arctic seep communities is limited to a few studies in the Barents and Beaufort seas (Åström et al., 2016, 2017a, b; Gebruk et al., 2003; Lösekann et al., 2008; Paull et al., 2015; Pimenov et al., 2000; Rybakova (Goroslavskaya) et al., 2013). The most well studied seep site in the Arctic is the Håkon Mosby mud volcano (HMMV), which has practically become synonymous with Arctic seep biology. Paradoxically, high thermal gradients in the sedi- 
ment have led researchers to conclude that HMMV does not really constitute a typical cold seep (Gebruk et al., 2003).

Another limitation to our current understanding of cold seeps is the focus on mainly deep-sea sites. It should be noted that the terms "shallow" and "deep" are relative, and a strict, universally accepted cutoff value separating the two does not exist. Nonetheless, relatively shallow seeps, such as those on continental shelves and upper continental slopes, have not been studied nearly as well as their deep-sea counterparts. In their reviews of cold seeps, Sibuet and Olu (1998, 2002) only considered sites at a minimum of $400 \mathrm{~m}$ water depth and even the more recent review of Levin et al. (2016) refers to cold seeps within the context of the deep sea. Yet studies of seeps in comparatively shallow water $(<400 \mathrm{~m})$ are crucial to resolve depth-related trends in biodiversity, chemosymbiotic species and seep-obligate fauna (Carney et al., 1983; Dando, 2010; Sahling et al., 2003).

Several sites of methane seepage have been discovered on the continental shelf offshore Svalbard and in the northwestern Barents Sea (Andreassen et al., 2017; Åström et al., 2016; Portnov et al., 2016; Sahling et al., 2014; Serov et al., 2017). An abundance of cold seeps in the Arctic is important, because the Arctic is connected to both the Pacific and the Atlantic Oceans. This setting provides an excellent opportunity to study the establishment of biogeographic provinces, migration and connectivity between seep populations that are otherwise disconnected from each other at lower latitudes. The presence of numerous cold seeps on the Barents Sea shelf could also be pertinent to the overall ecology and economy of the Arctic. The Barents Sea is considered an ecological hotspot for the circumpolar Arctic and an economically important region supporting one of the richest fisheries in the world (Carroll et al., 2018; Haug et al., 2017; Wassmann et al., 2011). The interaction between cold Arctic and warm Atlantic water masses, seasonal sea ice cover and the interplay of pelagic-benthic coupling creates a highly productive region (Degen et al., 2016; Ingvaldsen and Loeng, 2009; Sakshaug et al., 2009; Tamelander et al., 2006). Moreover, the Arctic and particularly the Barents Sea are predicted to experience amplified impacts of climate warming such as shrinking sea ice cover, changing oceanographic patterns and increasing ocean acidification (Haug et al., 2017; Onarheim and Årthun, 2017; Węsławski et al., 2011). Such climatic and environmental changes in the region and the associated impact of newly established invasive and northward migratory species may cause major ecological shifts in the Barents Sea (Cochrane et al., 2009; Degen et al., 2016; Johannesen et al., 2012). With our limited knowledge of the biology and ecology of Arctic seeps, predictions about how these methanebased ecosystems will respond to a warming Arctic are difficult to make.

This study examines the visible faunal community associated with a cold-seep site on the Arctic shelf in the western Barents Sea (Fig. 1). Our results serve as a first step towards addressing some of the existing gaps in our knowl-
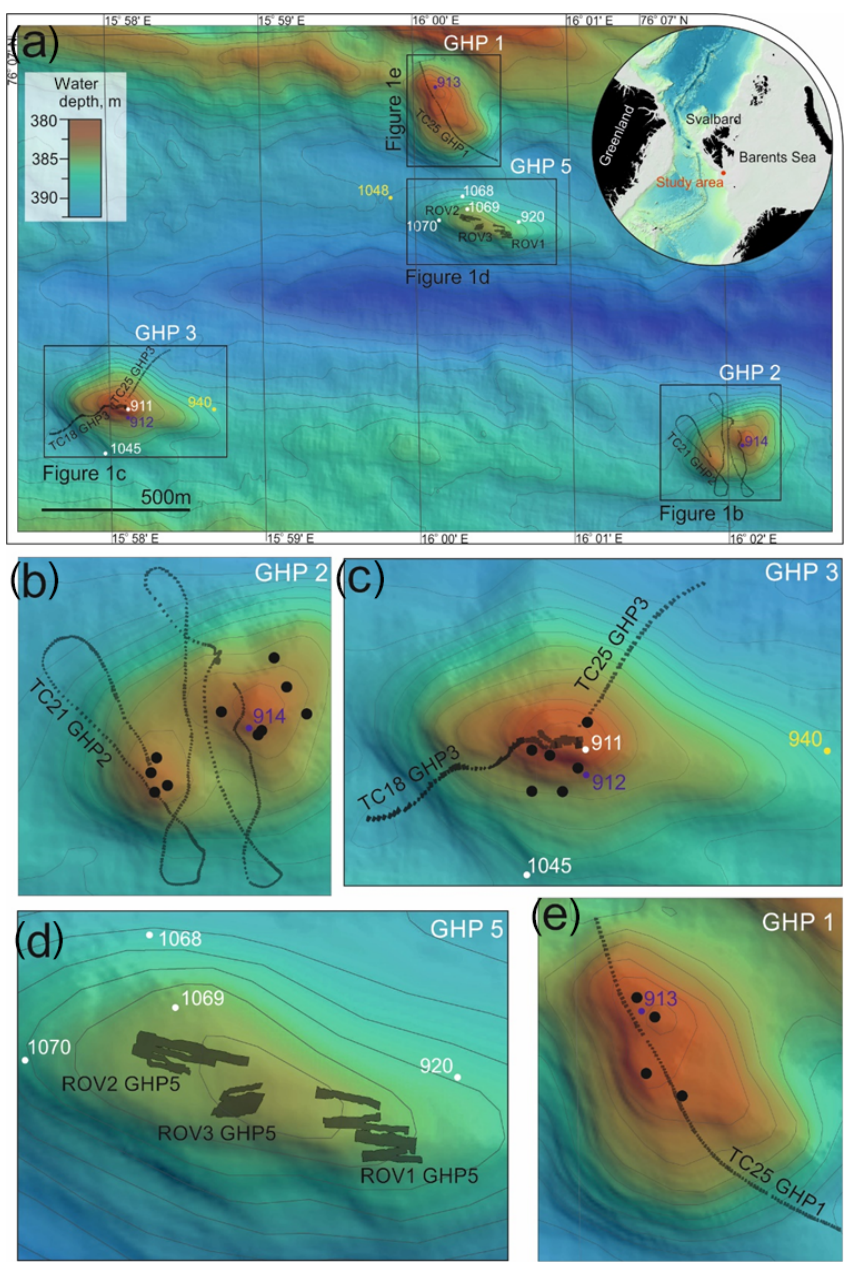

Figure 1. Location of the gas hydrate pingo (GHP) study site in the Barents Sea and overview of the site (a). Panels (b) through (e) are close-up views of the individual pingos. Free gas plumes were observed at all GHPs except GHP5 and their locations are marked with large black circles in panels (b-e). Image transects are visible as lines over the pingos where each constituent image is shown as a single dark rectangle. Mosaics on GHP5 are shown as larger, irregular-sized polygons. The small colored dots represent the locations of the gravity core samples: white represents cores in which all geochemical measurements were made (sulfide, sulfate, DIC, magnesium, calcium and methane), yellow dots are cores in which all geochemical measurements except methane were made, and purple dots represent cores from which only methane was measured.

edge regarding cold seep and Arctic ecology, i.e., with respect to seeps on the continental shelf in relatively shallow water $(<400 \mathrm{~m})$ in the high Arctic $\left(76^{\circ} \mathrm{N}\right)$ (Åström et al., 2016, 2017b; Dando, 2010; Paull et al., 2015).

High-resolution, georeferenced seabed imagery was used for analyzing the communities of visible fauna associated with four gas hydrate bearing mounds (pingos) exhibiting active methane seepage. All animals visible in the images (i.e., at least a few centimeters in size) were examined, thereby resulting in the inclusion of different categories of animals 
such as epifauna, infauna and even some pelagic species. We refer to these animals as megafauna, and by that, we mean animals large enough to be seen with the naked eye (Danovaro, 2009), which is consistent with a number of other imagebased studies (Amon et al., 2017; Baco et al., 2010; Bowden et al., 2013; Hessler et al., 1988; Lessard-Pilon et al., 2010; Marcon et al., 2014; Podowski et al., 2009, 2010; Rybakova (Goroslavskaya) et al., 2013; Sellanes et al., 2008; Sen et al., 2013, 2014, 2016, 2017). Multiple long-term hydroacoustic surveys were conducted at the pingos over 3 years and across different seasons. These surveys revealed flares of gas rising into the water column from around the summits of three of the four investigated pingos, suggesting different seepage regimes and sediment geochemical conditions between the free-gas-emitting pingos and the single pingo from which no hydroacoustic flares were seen. We hypothesized that megafaunal communities at the free-gas-emitting and nonemitting pingos would differ. Further, we expected differences in the concentrations of sulfide and methane in sediment pore water between the gas-emitting pingos and nonemitting pingo, to account for differences in associated megafaunal communities. The setting for this study is particularly useful for teasing apart the factors affecting the large-scale distribution of chemosynthesis-based species, since these animals are directly reliant on seeping chemicals (Levin, 2005; Sibuet and Olu, 1998). Chemosynthesis-based animals are often considered ecosystem engineers within cold-seep systems, and their presence or absence may subsequently affect community structure as a whole (Cordes et al., 2010; Levin, 2005; Levin et al., 2016). Our approach consisted of linking overall seepage patterns to sediment geochemistry and the distribution patterns of chemosynthesisbased animals in the context of the overall community structure.

\section{Methods and materials}

\subsection{Study site}

The area of focus for this study is a site on the Arctic shelf (hereafter referred to as the "pingo site"), about $50 \mathrm{~km}$ south of Sørkapp (South Cape), Spitsbergen, characterized by subcircular, domed seabed structures (Fig. 1) from which gas hydrates have been recovered in sediment cores (Hong et al., 2017). The morphological similarity of these mounds to terrestrial and offshore pingos have resulted in them being referred to as "gas hydrate pingos" (GHPs) (Serov et al., 2017). Originally, the term pingo referred to mounds of earth-covered ice in permafrost regions, formed by the hydrostatic pressure of water in the permafrost (Pissart, 1985). Similar features in marine systems, where sediment gas hydrates are analogous to ice in terrestrial systems, have been referred to as gas hydrate pingos or submarine pingos (Chapman et al., 2004; Hovland and Svensen, 2006; Paull et al.,
2007; Serié et al., 2012). In this study, the term gas hydrate pingos, or simply, pingos, will be used for the four features of interest.

The pingo site is located at a depth of about $380 \mathrm{~m}$, on the flank of the glacially eroded Storfjordrenna cross-shelf trough. A stable grounded ice sheet over Storfjordrenna, followed by alternating warm and cold periods, resulted in both the accumulation of gas hydrates as well as their episodic dissociation over the past 22000 years (Serov et al., 2017). The GHPs themselves are proposed to have been formed $\sim 15500$ years ago, when deglaciation followed by a warm Heinrich $\mathrm{H} 1$ event had a particularly debilitating effect on the gas hydrate stability zone (GHSZ) and resulted in the large-scale release of methane from gas hydrates that had accumulated during the prior thousands of years. Since about 8000 years ago, however, the region experienced a steady transition to current conditions of stable gas hydrates (Serov et al., 2017).

This study focuses on a cluster of four GHPs, within an area of $2 \mathrm{~km}^{2}$. These GHPs rise gradually above the surrounding seafloor $(8-12 \mathrm{~m})$ with diameters ranging between 280 and $450 \mathrm{~m}$. Hydroacoustic, seismic and geochemical surveys show persistent and continuous release of predominantly thermogenic methane gas around the summits of three of the four GHPs (GHPs 1,2 and 3) (Serov et al., 2017). No such free gas emissions were seen over GHP5 during repeat on-site observations over 3 years (2013-2016) across different seasons.

\subsection{Imagery}

Two sets of seafloor imagery were collected in 2015 and 2016 (Fig. 1). The first set was taken in 2015, with the MISO-WHOI (Multidisciplinary Instrumentation in Support of Oceanography, Woods Hole Oceanographic Institution) towed camera (tow cam for short) aboard the R/V Helmer Hanssen (cruise number CAGE-15_2). The tow cam consisted of a 16-megapixel digital still camera with optical image stabilization (photo resolution: $4928 \times 3264$ pixels). It was mounted on a frame that also contained six cores $(\sim 1 \mathrm{~m}$ long) and six Niskin bottles. Due to space limitations and the logistical difficulties with mounting the cores and the camera together on the main body of the frame, the downward-facing camera was tilted by $25^{\circ}$. Images were taken every $10-15 \mathrm{~s}$. Despite slow ship speeds, overlap between successive images could not be achieved, and therefore the tow cam image surveys were essentially transects over the different GHPs. The dataset consisted of one transect each over GHP1 and GHP2, and two transects over GHP3. Transects were named with an acronym for tow cam, followed by the dive number and the pingo number (e.g., TC25 GHP1). Navigation files from additional transects over GHP3 were inadequate for georeferencing purposes, and therefore the images associated with these transects were only used qualitatively to ascertain species' presence or absence. 
The second set of images was taken in 2016, also aboard Helmer Hanssen (cruise number CAGE-16_5). During this cruise, images were acquired via a pair of stereo cameras mounted on a remotely operated vehicle (ROV), 30K, operated by the Norwegian University for Science and Technology (NTNU). The stereo cameras (GC1380 digital still cameras, image resolutions of $1360 \times 1024$ pixels) were spaced $40 \mathrm{~cm}$ apart linearly, ensuring more than $50 \%$ overlap between left and right cameras, and faced downward at an angle of $35^{\circ}$. Due to higher maneuverability and control over an ROV in comparison to the tow cam, the imagery surveys in 2016 were conducted with the purpose of constructing mosaics (i.e., overlapping images taken in a lawn-mower fashion). Three mosaicking surveys were conducted over GHP5. Mosaics were named ROV, followed by the mosaic number and GHP5 (e.g., ROV1 GHP5). Navigation at GHP3 was unreliable, and therefore the corresponding images were unusable for quantitative analyses. However, these images were used to conduct a comparison of animals visually identifiable in the tow cam and ROV images.

\subsection{Mosaicking and georeferencing}

Neither the tow cam system nor the ship had closed loop positioning systems during the 2015 cruise. Using the length of the tow cam system's cable to correct image location proved unsuccessful, and therefore the ship's coordinates were used for positioning the tow cam images in space. At the scale of the site, this level of georeferencing is more than adequate, for it could be used to differentiate between different pingos and overall locations over them (summits, flanks, etc.). The ROV images were georeferenced based on coordinates obtained through an ultra-short baseline (USBL) closed positioning system. Images were mosaicked with the IFREMER software, Matisse v3 (courtesy of Aurélien Arnaubec). This software takes angles of tilt into account for estimating the footprints of images on the seafloor and uses navigation data for placing the mosaics in space. In the case of the tow cam images, since no overlap existed between images, the GeoTIFF output from Matisse v3 consisted of single images in space based on the coordinates of the image (Fig. 2). With the ROV images, the software produced a georeferenced mosaic as the GeoTIFF output. Due to the low-quality blending process of Matisse, higher quality seamless mosaics using a customized mosaicking script within MATLAB (Pizarro and Singh, 2003; Singh et al., 2004) were constructed, which were subsequently georeferenced by matching and lining up easily identifiable features to the same features in the Matisse mosaics (Fig. 2). All georeferenced images and mosaics were displayed within ArcGIS (ArcMap 10.3 and 10.5).

\subsection{Faunal identification and community analyses}

Visible fauna (at least a few centimeters across) were identified to the lowest possible taxonomic division and marked manually (Table 1). While the majority of fauna would be considered epifauna, animals partially buried in the sediment were also included, and a few species were present on the seafloor that could more generally be considered pelagic (e.g., ctenophores). Each individual was marked and the raw numbers were standardized to the different areas of the mosaics and transects by converting to densities based on the size of the mosaic or transect area.

Numerous mats or aggregations of siboglinid worms were seen, both in the tow cam and ROV images (Fig. A1). A number of these aggregations were sampled with cores and scoop nets and collected specimens were found to be frenulates lacking pinnules on the tentacles. This narrowed down the species identity to two possibilities: Oligobrachia haakonmosbiensis or Oligobrachia webbi (Brattegard, 1966; Smirnov, 2000). These two species are similar in terms of morphology and while officially they are considered different species (Smirnov, 2000, 2014), a consensus does not exist on this separation (e.g., Meunier et al., 2010). Since no DNA sequences are available for $O$. webbi, similar worms from other Arctic seeps have been referred to as $O$. haakonmosbiensis due to close affinities in mitochondrial COI (mitochondrial cytochrome $c$ oxidase subunit I) sequences with this species (Lösekann et al., 2008; Paull et al., 2015). For the sake of consistency with other Arctic seep studies, we will refer to the species in this study as $O$. cf. haakonmosbiensis. A comprehensive picture of the penetration depth of the worms was not obtained for this study; however, rough estimates indicate that individuals reached up to $50-60 \mathrm{~cm}$ in length. The tube diameter of these worms is about $500 \mu \mathrm{m}$, and therefore single individuals were not visible in the images, making it impossible to count or mark individual frenulates in the mosaics or image transects. Therefore, aggregations were outlined and the average density of 7000 individuals $\mathrm{m}^{-2} \mathrm{ob}-$ tained from core samples taken during 2016 was applied to the aggregation outlines in order to estimate total numbers of individuals within aggregations and densities in the transects or mosaics as a whole.

Though single individuals were visible of the small solitary Caryophyllia coral, it was not feasible to mark every individual of this taxon in the images either due to aggregations containing large numbers of individuals. Aggregations of the two morphotypes (pink and white) of Caryophyllia corals were outlined, similar to the siboglinids; however, densities from samples could not be applied to the outlined aggregations for estimating numbers of individuals since Caryophyllia tends to populate hard surfaces which were avoided during core sampling. Instead, six Caryophyllia aggregations were selected at random for each morphotype from the mosaics and image transects, and the number of individuals present in each aggregation were counted. Among the randomly chosen aggregations, on average, 27 individuals of the pink morphotype were seen (within an average aggregation size of $116 \mathrm{~cm}^{2}$ ) and 28 individuals of the white morphotype were seen (within an average aggregation size of $34 \mathrm{~cm}^{2}$ ). 
Table 1. Total numbers of individuals, aggregations and densities of fauna seen, listed by mosaic or transect. For each taxon, the first number represents the number of individuals, or the number of aggregations in the case of fauna where counting and marking each individual was not possible. Aggregated taxa are marked by a + sign. The number in parentheses refers to the density, calculated based on the area of each mosaic or transect (in the case of frenulates, densities were calculated based on collections and in the case of Caryophyllia corals, densities were calculated based on selecting a few aggregations per site and counting individuals within aggregations). In the case of bacterial mats, the number in parentheses refers to the density of mats per unit area, since density of individuals of bacteria cannot be counted. Taxa with a $*$ were not used in community analyses. Taxa marked with $\wedge$ were seen in images over GHP3 that could not be used due to navigational difficulties associated with that particular lowering of the towed camera.

\begin{tabular}{|c|c|c|c|c|c|c|c|}
\hline \multirow[b]{2}{*}{ Phylum and taxon } & \multicolumn{7}{|c|}{ Number of individuals or aggregations (density) } \\
\hline & TC21 GHP2 & TC18 GHP3 & TC25 GHP1 & TC25 GHP3 & ROV1 GHP5 & ROV2 GHP5 & ROV3 GHP5 \\
\hline \multicolumn{8}{|l|}{ Nonanimals } \\
\hline Bacterial mats*+ & $1078(0.63)$ & $1313(0.96)$ & $216(0.27)$ & $40(0.09)$ & $26(0.03)$ & $6(0.01)$ & $2(0.01)$ \\
\hline Carbonates (and other rock features)* & $1558(0.91)$ & $93(0.07)$ & $4161(5.28)$ & $2(0.004)$ & $918(1.16)$ & $296(0.46)$ & $985(3.08)$ \\
\hline \multicolumn{8}{|l|}{ Porifera } \\
\hline Phakellia sp. (elephant ear sponge) & $5(0.003)$ & $0(0)$ & $6(0.01)$ & $0(0)$ & $7(0.01)$ & $2(0.003)$ & $5(0.02)$ \\
\hline Thenea sp. (possibly valdiviae) & $1381(0.81)$ & $772(0.57)$ & $74(0.09)$ & $265(0.57)$ & $102(0.13)$ & $103(0.16)$ & $47(0.15)$ \\
\hline Stylocordyla borealis (stalked sponge) & $1(0.001)$ & $0(0)$ & $2(0.003)$ & $1(0.002)$ & $1(0.001)$ & $0(0)$ & $1(0.003)$ \\
\hline Unknown species 1 (white) & $0(0)$ & $0(0)$ & $8(0.01)$ & $0(0)$ & $5(0.01)$ & $0(0)$ & $0(0)$ \\
\hline Unknown species 2 (encrusting, yellow) & $0(0)$ & $0(0)$ & $5(0.01)$ & $0(0)$ & $2(0.003)$ & $0(0)$ & $41(0.13)$ \\
\hline Unknown species 3 (stick sponge) & $0(0)$ & $0(0)$ & $6(0.01)$ & $0(0)$ & $0(0)$ & $0(0)$ & $5(0.02)$ \\
\hline Unknown species 4 (encrusting, white) & $78(0.05)$ & $15(0.01)$ & $187(0.24)$ & $1(0.002)$ & $200(0.25)$ & $264(0.41)$ & $374(1.17)$ \\
\hline Unknown species 5 (white) & $0(0)$ & $0(0)$ & $5(0.01)$ & $0(0)$ & $0(0)$ & $0(0)$ & $1(0.003)$ \\
\hline \multicolumn{8}{|l|}{ Cnidaria } \\
\hline Bolocera sp. & $185(0.11)$ & $96(0.07)$ & $197(0.25)$ & $4(0.01)$ & $137(0.17)$ & $77(0.12)$ & $149(0.47)$ \\
\hline Caryophyllia sp. (pink)+ & $2(0.01)$ & $13(0.39)$ & $18(1.38)$ & $0(0)$ & $5(0.17)$ & $6(0.01)$ & $4(2.24)$ \\
\hline Caryophyllia sp. (white)+ & $88(1.94)$ & $4(0.001)$ & $646(11.56)$ & $1(0.02)$ & $2(0.08)$ & $0(0)$ & $3(0.69)$ \\
\hline Cerianthus sp. (soft bottom anemone) & $117(0.07)$ & $76(0.06)$ & $42(0.05)$ & $2(0.004)$ & $19(0.02)$ & $9(0.01)$ & $7(0.02)$ \\
\hline Corymorpha & $29(0.02)$ & $6(0)$ & $54(0.07)$ & $0(0)$ & $16(0.02)$ & $10(0.02)$ & $31(0.1)$ \\
\hline Drifa glomerata (cauliflower coral) & $0(0)$ & $0(0)$ & $6(0.01)$ & $0(0)$ & $0(0)$ & $0(0)$ & $1(0)$ \\
\hline Edwardsiidae & $47(0.03)$ & $22(0.02)$ & $187(0.24)$ & $1(0)$ & $7(0.01)$ & $0(0)$ & $0(0)$ \\
\hline Gersemia sp. (orange) & $85(0.05)$ & $104(0.08)$ & $206(0.26)$ & $31(0.07)$ & $1(0.001)$ & $0(0)$ & $2(0.01)$ \\
\hline Gersemia sp. (white) & $1001(0.58)$ & $410(0.3)$ & $621(0.79)$ & $240(0.51)$ & $380(0.48)$ & $313(0.49)$ & $328(1.03)$ \\
\hline Hormathia sp. & $120(0.07)$ & $34(0.02)$ & $82(0.1)$ & $0(0)$ & $65(0.08)$ & $58(0.09)$ & $0(0)$ \\
\hline Juvenile anemones & $189(0.11)$ & $351(0.26)$ & $404(0.51)$ & $199(0.43)$ & $118(0.15)$ & $5(0.01)$ & $120(0.38)$ \\
\hline Liponema multicornis (pom pom anemone) & $38(0.02)$ & $35(0.03)$ & $15(0.02)$ & $14(0.03)$ & $17(0.02)$ & $5(0.01)$ & $4(0.01)$ \\
\hline Lucernaria quadricomis (stalked jellyfish) & $4(0.002)$ & $1(0.001)$ & $1(0.001)$ & $0(0)$ & $0(0)$ & $0(0)$ & $0(0)$ \\
\hline Unknown actinarian 1 (small solitary corals) & $15(0.01)$ & $20(0.01)$ & $50(0.06)$ & $8(0.02)$ & $4(0.01)$ & $0(0)$ & $3(0.01)$ \\
\hline Unknown actinarian 2 (bright orange) & $43(0.03)$ & $0(0)$ & $0(0)$ & $0(0)$ & $0(0)$ & $2(0.003)$ & $0(0)$ \\
\hline Unknown medusa & $0(0)$ & $0(0)$ & $13(0.02)$ & $0(0)$ & $0(0)$ & $0(0)$ & $0(0)$ \\
\hline Unknown octocoral 1 (orange) & $103(0.06)$ & $5(0.004)$ & $25(0.03)$ & $6(0.01)$ & $0(0)$ & $0(0)$ & $1(0.003)$ \\
\hline Unknown octocoral 2 (yellow) & $0(0)$ & $10(0.01)$ & $0(0)$ & $0(0)$ & $0(0)$ & $0(0)$ & $0(0)$ \\
\hline \multicolumn{8}{|l|}{ Ctenophora } \\
\hline Beroe cucumis & $0(0)$ & $0(0)$ & $1(0.001)$ & $0(0)$ & $0(0)$ & $0(0)$ & $0(0)$ \\
\hline \multicolumn{8}{|l|}{ Nemertea } \\
\hline Nemertean, species unknown & $36(0.02)$ & $36(0.03)$ & $7(0.01)$ & $10(0.02)$ & $2(0.003)$ & $0(0)$ & $0(0)$ \\
\hline \multicolumn{8}{|l|}{ Priapulida } \\
\hline Priapulid, species unknown & $0(0)$ & $0(0)$ & $1(0.001)$ & $0(0)$ & $0(0)$ & $0(0)$ & $0(0)$ \\
\hline \multicolumn{8}{|l|}{ Sipuncula } \\
\hline Sipunculid, species unknown & $81(0.05)$ & $53(0.04)$ & $53(0.07)$ & $0(0)$ & $0(0)$ & $0(0)$ & $0(0)$ \\
\hline
\end{tabular}


Table 1. Continued.

\begin{tabular}{|c|c|c|c|c|c|c|c|}
\hline \multirow[b]{2}{*}{ Phylum and taxon } & \multicolumn{7}{|c|}{ Number of individuals and aggregations (density) } \\
\hline & TC21 GHP2 & TC18 GHP3 & TC25 GHP1 & TC25 GHP3 & ROV1 GHP5 & ROV2 GHP5 & ROV3 GHP5 \\
\hline \multicolumn{8}{|l|}{ Annelida } \\
\hline Aphrodita sp. (sea mouse) & $1(0.001)$ & $0(0)$ & $0(0)$ & $0(0)$ & $0(0)$ & $0(0)$ & $0(0)$ \\
\hline Nothria conchylega (onuphids)* & $270(0.16)$ & $170(0.12)$ & $311(0.39)$ & $559(1.2)$ & $0(0)$ & $0(0)$ & $0(0)$ \\
\hline Oligobrachia haakonmosbiensis (siboglinids)+ & $619(1059.92)$ & 947 (2144.19) & $339(671.45)$ & $0(0)$ & $0(0)$ & $0(0)$ & $0(0)$ \\
\hline Unknown species $1 *+$ & $0(0)$ & $15(\mathrm{n} / \mathrm{a})$ & $11(\mathrm{n} / \mathrm{a})$ & $0(0)$ & $0(0)$ & $0(0)$ & $0(0)$ \\
\hline Unknown species $2^{*}$ & $4(0.002)$ & $0(0)$ & $10(0.01)$ & $24(0.05)$ & $0(0)$ & $0(0)$ & $0(0)$ \\
\hline \multicolumn{8}{|l|}{ Arthropoda } \\
\hline Chionoecetes opilio (snow crab) $\wedge$ & $\mathrm{n} / \mathrm{a}$ & $\mathrm{n} / \mathrm{a}$ & $\mathrm{n} / \mathrm{a}$ & $\mathrm{n} / \mathrm{a}$ & $\mathrm{n} / \mathrm{a}$ & $\mathrm{n} / \mathrm{a}$ & $\mathrm{n} / \mathrm{a}$ \\
\hline Euphausiacea (krill) & $54(0.03)$ & $0(0)$ & $0(0)$ & $0(0)$ & $0(0)$ & $0(0)$ & $0(0)$ \\
\hline Pandalus borealis (northern shrimp) & $359(0.2)$ & $155(0.11)$ & $227(0.29)$ & $38(0.08)$ & $277(0.35)$ & $59(0.09)$ & $34(0.11)$ \\
\hline Pycnogonids & $483(0.28)$ & $249(0.18)$ & $76(0.1)$ & $12(0.03)$ & $0(0)$ & $0(0)$ & $1(0.003)$ \\
\hline \multicolumn{8}{|l|}{ Mollusca (Arthropoda) } \\
\hline Gastropods and hermit crabs & $64(0.04)$ & $53(0.04)$ & $54(0.07)$ & $9(0.02)$ & $6(0.01)$ & $3(0.005)$ & $1(0.003)$ \\
\hline \multicolumn{8}{|l|}{ Echinodermata } \\
\hline Chiridota sp. & $0(0)$ & $0(0)$ & $3(0)$ & $0(0)$ & $0(0)$ & $0(0)$ & $0(0)$ \\
\hline Сиситагіa sp. & $2(0.001)$ & $0(0)$ & $0(0)$ & $0(0)$ & $0(0)$ & $0(0)$ & $0(0)$ \\
\hline Elpidia sp. (sea pig) & $0(0)$ & $1(0.001)$ & $0(0)$ & $0(0)$ & $1(0.001)$ & $1(0.002)$ & $0(0)$ \\
\hline Henricia sp. (pink) & $4(0.002)$ & $0(0)$ & $0(0)$ & $0(0)$ & $0(0)$ & $0(0)$ & $0(0)$ \\
\hline Henricia sp. (white) & $2(0.001)$ & $0(0)$ & $0(0)$ & $0(0)$ & $1(0.001)$ & $0(0)$ & $1(0.003)$ \\
\hline Henricia sp. (orange) & $3(0.002)$ & $1(0.001)$ & $4(0.01)$ & $0(0)$ & $0(0)$ & $1(0.002)$ & $0(0)$ \\
\hline Henricia sp. (yellow) & $0(0)$ & $0(0)$ & $0(0)$ & $0(0)$ & $2(0.003)$ & $0(0)$ & $0(0)$ \\
\hline Holothuridae (species unknown) & $2(0.001)$ & $0(0)$ & $0(0)$ & $0(0)$ & $0(0)$ & $0(0)$ & $0(0)$ \\
\hline Molpadia borealis & $1(0.001)$ & $2(0.001)$ & $0(0)$ & $0(0)$ & $0(0)$ & $0(0)$ & $0(0)$ \\
\hline Ophiuroids & $123(0.07)$ & $106(0.08)$ & $208(0.26)$ & $0(0)$ & $0(0)$ & $0(0)$ & $9(0.03)$ \\
\hline Poraniomorpha sp. & $0(0)$ & $0(0)$ & $1(0.001)$ & $0(0)$ & $0(0)$ & $0(0)$ & $0(0)$ \\
\hline \multicolumn{8}{|l|}{ Chordata } \\
\hline Anarhichas minor (spotted wolffish) $\wedge$ & $\mathrm{n} / \mathrm{a}$ & $\mathrm{n} / \mathrm{a}$ & $\mathrm{n} / \mathrm{a}$ & $\mathrm{n} / \mathrm{a}$ & $\mathrm{n} / \mathrm{a}$ & $\mathrm{n} / \mathrm{a}$ & $\mathrm{n} / \mathrm{a}$ \\
\hline Gadus morhua (Atlantic cod) & $335(0.2)$ & $16(0.01)$ & $0(0)$ & $2(0.004)$ & $2(0.003)$ & $99(0.16)$ & $77(0.24)$ \\
\hline Gray tunicates+ & $0(0)$ & $0(0)$ & $8(0.01)$ & $0(0)$ & $0(0)$ & $0(0)$ & $0(0)$ \\
\hline Hippoglossoides platessoides (American plaice) & $5(0.003)$ & $5(0.003)$ & $1(0.001)$ & $0(0)$ & $2(0.003)$ & $0(0)$ & $0(0)$ \\
\hline Leptagonus sp. (snake blenny) & $0(0)$ & $1(0)$ & $0(0)$ & $0(0)$ & $0(0)$ & $0(0)$ & $0(0)$ \\
\hline Lycodes reticulatus & $1(0.001)$ & $1(0.001)$ & $0(0)$ & $0(0)$ & $1(0.001)$ & $0(0)$ & $0(0)$ \\
\hline Melanogrammus aeglefinus (haddock) & $0(0)$ & $0(0)$ & $0(0)$ & $0(0)$ & $0(0)$ & $0(0)$ & $1(0.003)$ \\
\hline Reinhardtius hippoglossoides (Greenland halibut) & $3(0.002)$ & $0(0)$ & $0(0)$ & $1(0.002)$ & $0(0)$ & $0(0)$ & $0(0)$ \\
\hline Skates & $4(0.002)$ & $1(0.001)$ & $0(0)$ & $1(0.002)$ & $1(0.001)$ & $1(0.002)$ & $1(0.003)$ \\
\hline Zoarcids (small) & $1(0.001)$ & $4(0.003)$ & $1(0.001)$ & $0(0)$ & $0(0)$ & $0(0)$ & $0(0)$ \\
\hline \multicolumn{8}{|l|}{ Others or unknown } \\
\hline White, possible scaphopod* & $46(0.03)$ & $89(0.07)$ & $56(0.07)$ & $44(0.09)$ & $0(0)$ & $0(0)$ & $0(0)$ \\
\hline
\end{tabular}

n/a: not applicable

These averages were used to estimate total numbers and overall densities for all remaining aggregations outlined in the mosaics and image transects.

An exception to the standard methodology of marking every visible taxon was a type of encrusting animal, possibly a bryozoan. Reddish, brownish and greenish morphotypes of this organism were seen, but given the difficulty in identifying them or even visualizing them sufficiently, these animals were neither marked in the image transects and mosaics nor discussed in this study.

The tow cam images captured more detail than the ROV stereo cameras. Therefore, before inclusion in the community analysis, the different taxa were evaluated both in terms of size and shape as well as their overall ability to be seen in images collected by the ROV stereo cameras. A total of
20 taxa identified in the tow cam images were not seen in the ROV images. Of these taxa, 12 were rare, i.e., only seen once, or at one site. These rare taxa were included in the community analyses because their absence from the ROV mosaics is likely not due to their inability to have been seen on the images, but rather due to their rare appearance. In order to determine whether the remaining 8 should be included in the community analyses, the ROV images from pingo 3 (with unreliable navigation data) were examined. Comparing the ROV GHP3 with the other ROV images (from GHP5) made it possible to explore whether animals not seen in the ROV GHP5 images was due to an inherent inability to see them in ROV images because of their lower resolution. Of these, juvenile fish, Molpadia borealis sea cucumbers, white possible scaphopods, the two unidentifiable polychaete species 

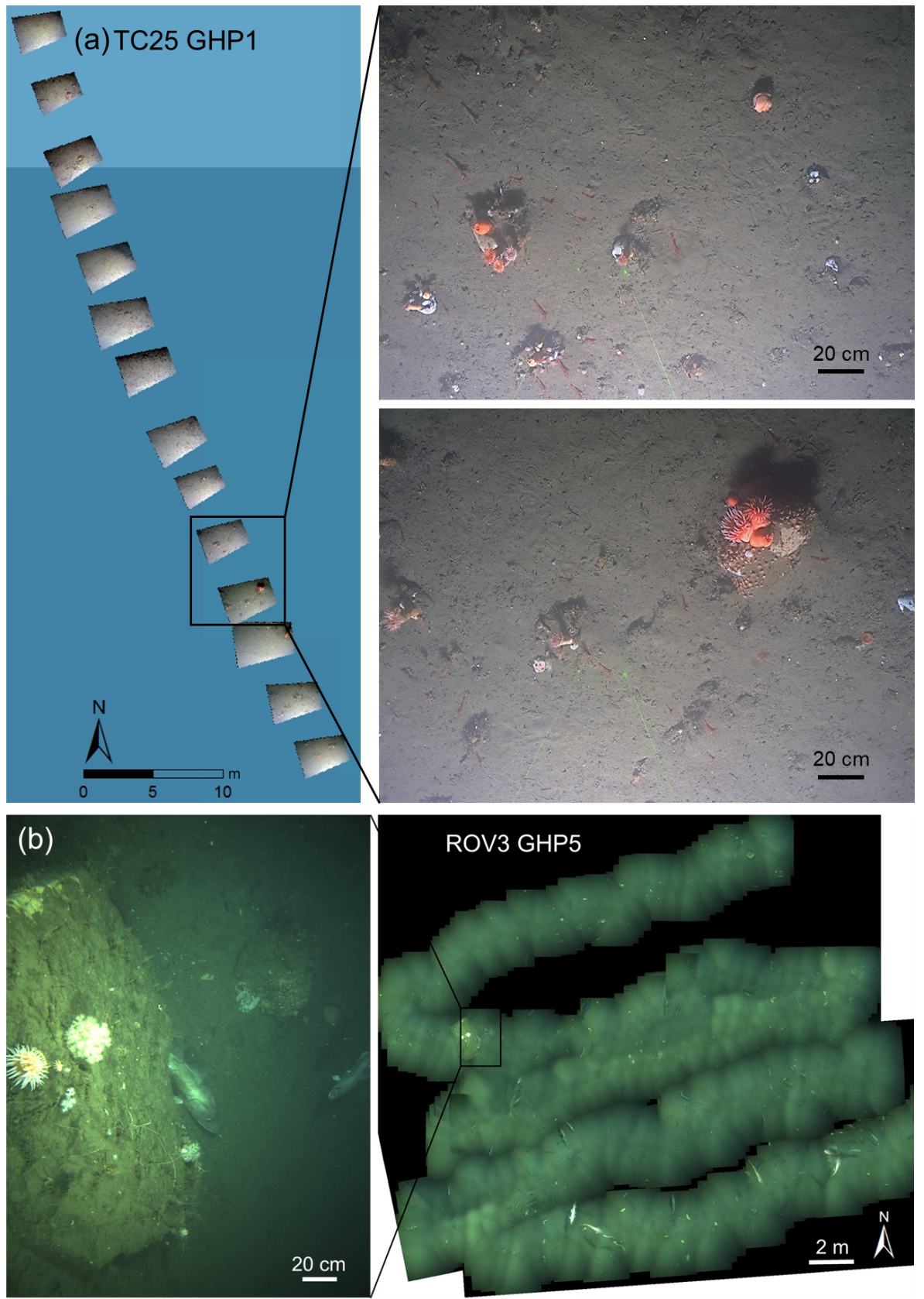

Figure 2. Examples of image transects and mosaics used in the study. (a) A portion of the TC25 image transect over GHP5. Individual images positioned in space are shown and close-up views of two of the images are shown to the right. (b) ROV mosaic 3 over GHP5, with a close-up view of one of the images used to construct the mosaic.

and the onuphid worm Nothria conchylega were not seen in the ROV GHP3 images. $M$. borealis sea cucumbers and juvenile fish tend to stick out more, and are larger than some of the smallest animals seen in the ROV images such as stick sponges and Pandalus borealis shrimp. Therefore they were considered detectable through the ROV stereo cameras and their absence from an ROV image was attributed to their actual absence and not due to their inability to be seen in those images. They were therefore included in the commu- nity analyses. The other animals that were not seen in the ROV GHP3 images were excluded from the community analyses because they likely would have been missed despite being present either because of their small size (e.g., white possible scaphopod) or because they blended into the background sediment (e.g., N. conchylega). In a few cases, this comparison between ROV images from GHP5 and GHP3 determined whether higher level taxa should be used. For example, pycnogonids were grouped together into a single 
category for community analyses despite at least three different morphotypes being visible in the tow cam images. Gastropods were all grouped together despite 10 morphotypes being visible in the tow cam images. Furthermore, hermit crabs (Pagurus sp.) were included in the gastropod category since it was not always clear whether gastropod shells were occupied by the original inhabitants or by hermit crabs. Similarly, all ophiuroids were grouped together, as were three morphotypes of zoarcid fish.

Overall densities of visible fauna were used in creating a Bray-Curtis similarity matrix, which was the basis for multidimensional scaling (MDS) and cluster analyses. A fourth root transformation was applied on the abundance data due to the vast range of densities among faunal groups, in order to balance the impact of both highly abundant and rare taxa within the same dataset. MDS and cluster analysis was conducted both with and without the inclusion of frenulates. In both iterations of community analyses, ANOSIM tests were run in order to test the significance of the cluster results.

\subsection{Geochemical measurements}

Gravity cores were recovered from the different GHPs in order to determine the general geochemical characteristics of sediment pore fluids (Fig. 1 and Table 2). In 2015, six gravity cores were taken: cores 911, 912 and 940 at GHP3; core 913 at GHP1; core 914 at GHP2; and core 920 at GHP5. Sulfide, sulfate, dissolved inorganic carbon (DIC) and methane were measured in cores 911 and 920. Methane was not measured in core 940, and only methane was measured in cores 912, 913 and 914. In 2016, five gravity cores were taken at GHP3 and GHP5, core 1045 was taken at GHP3, and cores 1048, 1068, 1069 and 1070 were taken at GHP5. All 2016 cores were subjected to the full array of geochemical analyses with the exception of core 1048, for which methane was not measured.

\subsubsection{Pore water measurements}

Details of the pore water sampling and analyses are given in Hong et al. (2017). Briefly, pore water samples were collected by inserting acid-washed rhizons into predefined depths of the sediment cores in the refrigerated room onboard. Quantities of 5-15 mL of water were collected in acidwashed syringes. The total alkalinity was measured by Gran titration method within $2 \mathrm{~h}$ after the syringes were disconnected from the rhizons. For the determination of total hydrogen sulfide concentration $\left(\Sigma \mathrm{H}_{2} \mathrm{~S}\right)$, an aliquot of water sample was preserved with saturated $\mathrm{Zn}(\mathrm{OAc})_{2}$ solution to prevent redissolution of sulfide within $0.5 \mathrm{~h}$. Samples were stored frozen until analyses were conducted in the lab. Concentrations of hydrogen sulfide were analyzed spectrophotometrically using the "Cline method" (Cline, 1969). The detection limit for the variant of this method used in this study is $40 \mu \mathrm{mol}$. Sulfate concentrations were measured from the same samples for sulfide analyses by ion chromatography. Concentrations of dissolved calcium and magnesium were measured by ICP-AES (inductively coupled plasma optical emission spectrometry). Both analyses were performed in the laboratory of the Geological Survey of Norway (NGU).

\subsubsection{Estimation of dissolved inorganic carbon (DIC) concentrations}

The concentration of DIC was approximated based on carbonate alkalinity which itself was estimated by subtracting the concentration of $\Sigma H S$ from total alkalinity. This is a reasonable assumption for the slightly basic pore water as bicarbonate ions are the dominant carbonate species in solution. To differentiate the different pathways of sulfate reduction, either through organic matter degradation or through coupling with anaerobic oxidation of methane (AOM), we estimated the values of $\triangle \mathrm{DIC}$ and $\Delta \mathrm{SO}_{4}$ based on the following equations (Claypool et al., 2006; Suess and Whiticar, 1989):

$$
\begin{aligned}
& \Delta \mathrm{DIC}=\left([\mathrm{DIC}]_{\mathrm{spl}}-[\mathrm{DIC}]_{\mathrm{BW}}\right) \\
& +\Delta \mathrm{Ca}^{2+}+\Delta \mathrm{Mg}^{2+}, \\
& \Delta \mathrm{SO}_{4}=\left[\mathrm{SO}_{4}\right]_{\mathrm{spl}}-\left[\mathrm{SO}_{4}\right]_{\mathrm{BW}}, \\
& \Delta \mathrm{Ca}^{2+}=\left[\mathrm{Ca}^{2+}\right]_{\mathrm{spl}}-\left[\mathrm{Ca}^{2+}\right]_{\mathrm{BW}}, \\
& \Delta \mathrm{Mg}^{2+}=\left[\mathrm{Mg}^{2+}\right]_{\mathrm{spl}}-\left[\mathrm{Mg}^{2+}\right]_{\mathrm{BW}},
\end{aligned}
$$

where []$_{\mathrm{spl}}$ and []$_{\mathrm{BW}}$ are the concentrations of various chemical species in pore water samples (spl) and bottom water (bw). We applied these calculations only to samples above the depth of the sulfate methane transition zone (SMTZ). Such an operation assumes that DIC is produced by organoclastic sulfate reduction and/or AOM-sustained sulfate reduction while carbonate precipitation, which consumes both calcium and magnesium, decreases DIC concentration. By plotting $\triangle \mathrm{DIC}$ against $\Delta \mathrm{SO}_{4}$, it is possible to differentiate the primary DIC production reactions based on different stoichiometric relationships. For every mole of organic matter degraded, one mole of sulfate is consumed and two moles of DIC will be produced. For AOM-sustained sulfate reduction, one mole of DIC is produced for every mole of sulfate consumed.

\subsubsection{Methane measurements}

Concentrations of pore water methane were obtained through conventional headspace sample preparation (Kolb and Ettre, 2006) and flame-ionized detector gas chromatography. The bulk sediment volume of $5 \mathrm{~mL}$ was placed in $20 \mathrm{~mL}$ headspace vials, $5 \mathrm{~mL}$ of 1 molar $\mathrm{NaOH}$ solution was added, and the vials were capped with rubber septa, sealed with aluminum crimp caps and shaken for $2 \mathrm{~min}$. Similar to the other measurements, samples were taken for methane measurements at predefined intervals along the lengths of the cores. Measurements were carried out using a TG-BOND Alumina 
Table 2. Properties of all the gravity cores taken and analyzed for the study. The measurements taken for each core are listed (sulfide concentration, sulfate concentration, excess inorganic carbon (DIC) and methane concentration).

\begin{tabular}{lccl}
\hline Core number & GHP number & Year & Measurements taken \\
\hline 911 & 3 & 2015 & sulfide, sulfate, DIC, methane, calcium, magnesium \\
912 & 3 & 2015 & methane \\
913 & 1 & 2015 & methane \\
914 & 2 & 2015 & methane \\
920 & 5 & 2015 & sulfide, sulfate, DIC, methane, calcium, magnesium \\
940 & 3 & 2015 & sulfide, sulfate, DIC, calcium, magnesium \\
1045 & 3 & 2016 & sulfide, sulfate, DIC, methane, calcium, magnesium \\
1048 & 5 & 2016 & sulfide, sulfate, DIC, calcium, magnesium \\
1068 & 5 & 2016 & sulfide, sulfate, DIC, methane, calcium, magnesium \\
1069 & 5 & 2016 & sulfide, sulfate, DIC, methane, calcium, magnesium \\
1070 & 5 & 2016 & sulfide, sulfate, DIC, methane, calcium, magnesium \\
\hline
\end{tabular}

$\left(\mathrm{Na}_{2} \mathrm{SO}_{4}\right) 30 \mathrm{~m} \times 0.53 \mathrm{~mm} \times 10 \mu \mathrm{m}$ column on a ThermoScientific Trace 1310 gas chromatograph. Free gas can mix with dissolved gas in this method; however, this may take place only if overall headspace concentrations measured in laboratory conditions exceed the solubility limit of methane under in situ pressure and temperature conditions. The concentrations in this study were below this critical value, and therefore our measurements are reflective of dissolved methane concentrations, although it should be kept in mind that free gas might also have been included to a small extent.

\subsection{Seismic data}

A seismic profile was generated from a broadband (10$350 \mathrm{~Hz})$ high-resolution $(\sim 6 \mathrm{~m}$ lateral and $2-3 \mathrm{~m}$ vertical resolution of the shallow subsurface) P-Cable 3-D seismic cube (R/V Helmer Hanssen cruise number CAGE 16-6, 2016). This P-Cable 3-D seismic system consisted of $1425 \mathrm{~m}$ long streamers, each containing 8 hydrophones. The streamers were spaced $12.5 \mathrm{~m}$ apart along a cross-cable towed perpendicular to the ships steaming direction. Seismic energy was generated using one mini-GI (generator injector) air gun of $45 \mathrm{in}^{3}\left(737.4 \mathrm{~cm}^{3}\right)$ volume, operated with an air gun pressure of 160 bar (Petersen et al., 2010 and Waage et al., 2018).

\section{Results}

\subsection{Community characteristics}

Bacterial mats were seen in every image transect or mosaic, confirming the presence of reduced chemicals in the sediment and seepage activity at every pingo, including GHP5. Fewer bacterial mats were seen on GHP5 in comparison to the other GHPs (Table 1). Hard substrates were also seen in every image transect or mosaic. Most of these hard substrates were clearly authigenic carbonates, distinguishable by their pitted texture. The texture of all rock-like features was not always visible in the images, either due to resolution is- sues or because of animals colonizing the surfaces. Therefore, some of the hard features could possibly be dropstones or other substrates not formed as a result of seepage activity. Nonetheless every GHP hosted carbonate structures, indicative of long-term gas seepage.

A total of 60 taxa were identified and marked in the image transects and mosaics (Table 1). Of these, 56 were used in the community analyses (see Sect. 2.4). In addition to the 60 taxa seen and marked in the mosaics and transects, two individuals of Chionoecetes opilio (snow crab) and a few individuals of the wolffish (Anarhichas minor) were seen in the images over GHP3 (Table 1). On average, 29 taxa were seen in single mosaics or image transects over the different pingos (this average is based on raw richness counts and does not account for the differences in areas covered by the mosaics and image transects). Many morphologically distinct taxa were grouped together as a single taxon on a number of occasions. For example, at least 10 morphologically distinct types of gastropods and 3 types of pycnogonids were seen. Therefore, the total taxonomic richness of the pingo site is likely considerably higher than the 62 taxa listed in Table 1 . Richness counts were similar between the various transects or mosaics, and furthermore, richness counts of the mosaics from the non-gas-emitting pingo (GHP5) were very similar to those at the gas-emitting pingos (Table 3). However, the diversity indices revealed that the gas-emitting pingos (except the TC25 transect over GHP3) were much less even than GHP5. This trend was only observed with siboglinids included in the analysis; with their removal, diversity indices did not display much variation between the individual pingos, mosaics or image transects.

In total, 11 animal phyla were seen (Porifera, Cnidaria, Ctenophora, Nemertea, Priapulida, Sipuncula, Annelida, Arthropoda, Mollusca, Echinodermata, and Chordata). Of these, cnidarians were represented by the largest number of taxa (18), followed by echinoderms (11) and chordates (10). The most abundant taxon by far was the frenulates, despite their absence from GHP5. The frenulate worms are the only 
Table 3. Diversity indices and taxonomic richness counts (total and normalized for area) for the different mosaics and transects over the study pingos.

\begin{tabular}{|c|c|c|c|c|c|c|c|}
\hline Mosaic or transect & $\begin{array}{r}\text { Mosaic or transect } \\
\text { area }\left(\mathrm{m}^{2}\right)\end{array}$ & Total richness & $\begin{array}{r}\text { Richness, } \\
\text { per } 100 \mathrm{~m}^{2}\end{array}$ & $\begin{array}{r}\text { Margalef's } \\
\text { index }(d)\end{array}$ & $\begin{array}{r}\text { Pielou's } \\
\text { evenness }(J)\end{array}$ & $\begin{array}{r}\text { Shannon } \\
\text { diversity }\left(H^{\prime}\right)\end{array}$ & $\begin{array}{r}\text { Simpson's } \\
\text { index }(1-\lambda)\end{array}$ \\
\hline \multicolumn{8}{|c|}{ with siboglinids included } \\
\hline TC21 GHP 2 & 1714.23 & 41 & 2.4 & 5.74 & 0.007 & 0.026 & 0.006 \\
\hline TC18 GHP 3 & 1363.22 & 33 & 2.4 & 4.17 & 0.003 & 0.009 & 0.002 \\
\hline TC25 GHP 1 & 787.63 & 39 & 5.0 & 5.83 & 0.016 & 0.057 & 0.013 \\
\hline TC25 GHP 3 & 467.56 & 20 & 4.3 & 32.04 & 0.578 & 1.732 & 1.703 \\
\hline ROV1 GHP 5 & 787.99 & 28 & 3.6 & 47.99 & 0.636 & 2.119 & 1.948 \\
\hline ROV2 GHP 5 & 637.52 & 18 & 2.8 & 36.32 & 0.666 & 1.926 & 2.156 \\
\hline ROV3 GHP 5 & 319.50 & 27 & 8.5 & 19.04 & 0.613 & 2.022 & 1.089 \\
\hline \multicolumn{8}{|l|}{ without siboglinids } \\
\hline TC21 GHP 2 & 1714.23 & 40 & 2.3 & 35.79 & 0.673 & 2.483 & 1.301 \\
\hline TC18 GHP 3 & 1363.22 & 32 & 2.3 & 46.43 & 0.684 & 2.37 & 1.756 \\
\hline TC25 GHP 1 & 787.63 & 38 & 4.8 & 24.78 & 0.726 & 2.641 & 1.159 \\
\hline TC25 GHP 3 & 467.56 & 20 & 4.3 & 32.04 & 0.578 & 1.732 & 1.703 \\
\hline ROV1 GHP 5 & 787.99 & 28 & 3.6 & 47.99 & 0.636 & 2.119 & 1.948 \\
\hline ROV2 GHP 5 & 637.52 & 18 & 2.8 & 36.32 & 0.666 & 1.926 & 2.156 \\
\hline ROV3 GHP 5 & 319.50 & 27 & 8.5 & 19.04 & 0.613 & 2.022 & 1.089 \\
\hline
\end{tabular}

known chemosynthetic species observed in the images used in this study and also the only potential seep-specific or seepobligate species. Following frenulates, the next most numerous taxa were Gersemia corals and Thenea sponges (likely Thenea valdiviae, Cárdenas and Rapp, 2012; Steenstrup and Tendal, 1982). The onuphid worm, Nothria conchylega was also abundant in the tow cam images and trails in the sediment were also seen behind these worms. Most of the cnidarians and the non-Thenea sponges were seen on hard substrates. A number of other animals were also seen on or near hard substrates, such as the northern shrimp (Pandalus borealis), ophiuroids and various gastropods. Pycnogonids were often seen among frenulate worm tufts. Conversely, pycnogonids were rare or absent in image transects or mosaics where frenulates were not present. Among the various taxa, several hold economic value, such as Atlantic cod (Gadus morhua), northern shrimp, haddock (Melanogrammus aeglefinus) and Greenland halibut (Reinhardtius hippoglossoides) (Norwegian Directorate of Fisheries, 2017).

The community analysis including frenulates resulted in communities on mosaics and transects that can be separated into two distinct clusters ( $R=0.926, p=0.03$, Fig. 3a). This clustering corresponded to communities containing frenulate aggregations and communities without frenulate aggregations. In other words, the GHP5 mosaics, and the TC25 transect over GHP3 formed one cluster, while the other GHP3 transect and the transects over GHP1 and GHP2 formed a separate cluster. When frenulates were excluded from the analysis, a similar result was obtained, with two clusters corresponding to communities and mosaics from GHP5 and communities and transects from the other GHPs. This clustering was also significant $(R=0.7044, p=0.03$, Fig. $3 b)$.

\subsection{Sediment geochemistry and subsurface features}

Sulfide was below the detection limit $(40 \mu \mathrm{M})$ in the bottom water. In most cores, the first sediment layers where measurements were taken tended to contain undetectable or very low concentrations as well. Subsequently, sulfide concentrations rapidly increased downcore, with high millimolar-level concentrations measured across all cores (Fig. 4a). The sulfide profiles of cores taken from GHP5 did not appear to differ substantially from sulfide profiles of cores from GHP3 (Fig. 4a). Methane was detectable at the sediment surface and often remained more or less constant, until large increases were measured below $40 \mathrm{~cm}(50 \mathrm{~cm}$ for GHP5 cores). At depth, methane concentrations tended to be lower in cores taken from GHP5 in comparison to the cores from the other pingos (Fig. 4b).

At both GHP3 and GHP5, by and large, a 1:1 correspondence was observed between increase in inorganic carbon and increase in sulfate $\left(\triangle \mathrm{DIC}\right.$ and $\left.\Delta \mathrm{SO}_{4}\right)$ in both shallow and deeper sediment, suggesting that most sulfate reduction in the sediment is linked to anaerobic oxidation of methane (Fig. 5). In some cores, a switch from a $2: 1$ to a $1: 1$ ratio was observed (e.g., core 940, Fig. 5). Core 1045 from GHP5 was the only core in which even values from deeper in the sediment corresponded more closely to the $2: 1$ ratio, indicative of organic matter degradation via sulfate-reducing bacteria being the major consumer of sulfate. Therefore, at both GHP3 and GHP5, sulfate reduc- 


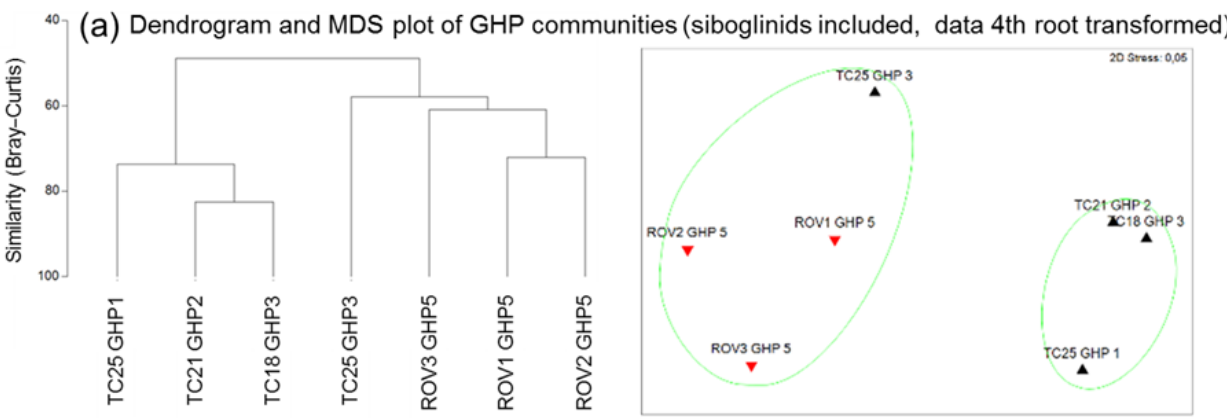

(b) Dendrogram and MDS plot of GHP communities (siboglinids not included, data 4th root transformed)
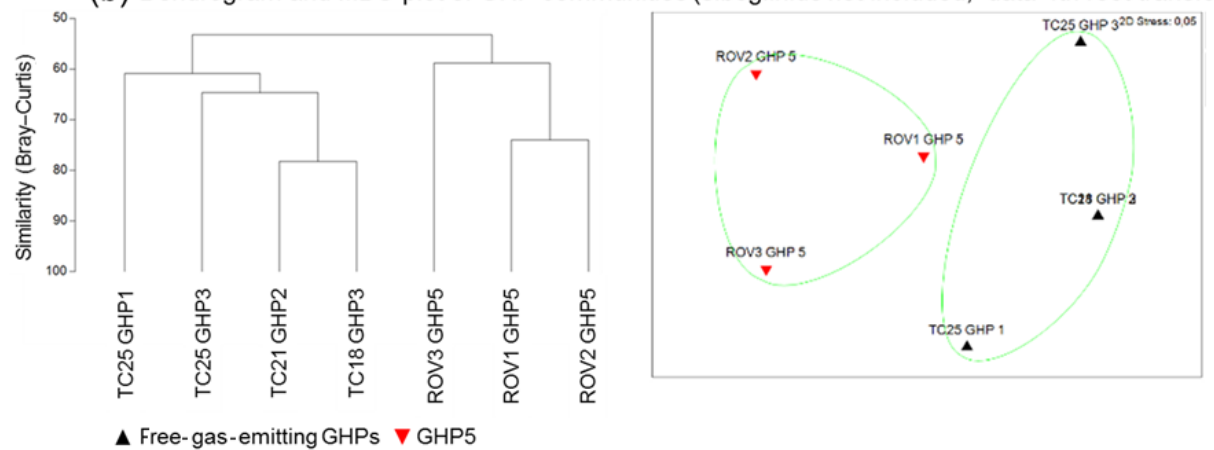

Figure 3. Dendrograms and MDS plots of the communities seen in the mosaics and transects over the different gas hydrate pingos. Panel (a) shows the results with frenulates included in the community analysis $(R=0.926, p=0.03)$ while panel (b) shows the results without frenulates $(R=0.704, p=0.03)$. In both cases, a fourth root transformation was applied to the densities, and the Bray-Curtis similarity was used. In the bottom MDS plot, TC21 GHP2 and TC18 GHP3 are so similar that their representative triangles almost completely overlap.
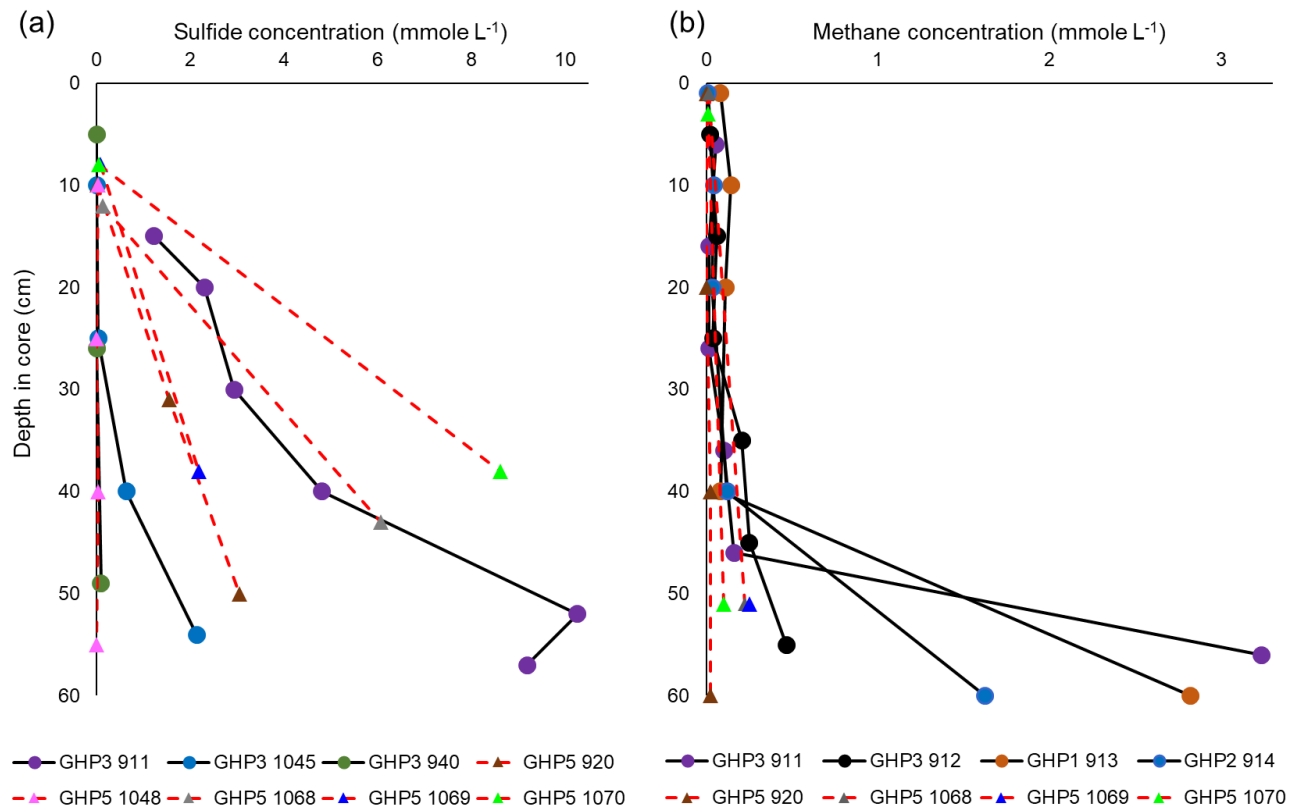

Figure 4. Concentrations of sulfide (a) and methane (b) in gravity core samples. Cores from GHP5 are represented with red, dashed lines connecting individual measurements (filled triangles) within the cores. Solid black lines and filled circles represent cores from the other GHPs (GHP1, GHP2 and GHP3). Methane data from cores 911, 912, 913, 914 and 920 are reproduced from Serov et al. (2017). Sulfide data from cores 911, 920 and 940 are reproduced from Hong et al. (2017). 


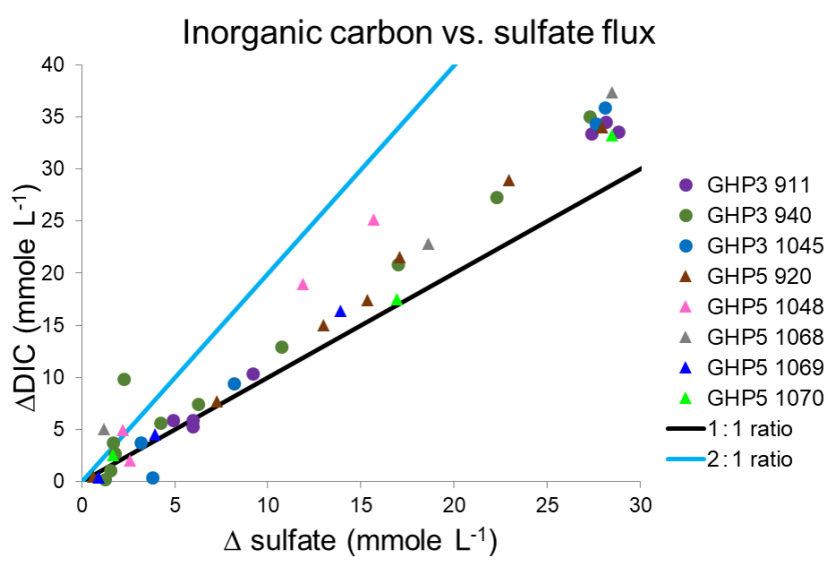

Figure 5. Excess inorganic carbon $\left(\Delta \mathrm{CO}_{2}+\mathrm{Mg}+\Delta \mathrm{Ca}\right)$ plotted against sulfate flux (consumption) in gravity cores from GHP3 and GHP5. The sediment depth range from where measurements were taken in the cores is listed individually for each core in Table 4 . The solid lines represent the theoretical relationships for a $2: 1$ and $1: 1$ ratio of inorganic carbon:sulfate, where a $2: 1$ relationship represents use of sulfate by sulfate-reducing bacteria in the breakdown of organic matter, and a $1: 1$ relationship represents sulfate reduction linked to methane oxidation.

of organic matter (Fig. 5). Further, the rate of sulfate consumption appears to differ between GHP3 and GHP5. Sulfate flux rates ranged from -0.31 to $-2.08 \mathrm{~mol} \mathrm{~m}^{-2} \mathrm{day}^{-1}$ in cores from GHP3. The lowest rate of sulfate flux was measured in a core from GHP5 $\left(-0.12 \mathrm{molm}^{-2}\right.$ day $\left.^{-1}\right)$ and the maximum rate of sulfate flux measured in cores from GHP5 was only $-0.9 \mathrm{~mol} \mathrm{~m}^{-2} \mathrm{day}^{-1}$. On average, the rate of sulfate flux measured in cores from GHP5 $\left(-0.57 \mathrm{~mol} \mathrm{~m}^{-2} \mathrm{day}^{-1}\right)$ was lower in comparison to cores from GHP3 $\left(-1.22 \mathrm{~mol} \mathrm{~m}^{-2} \mathrm{day}^{-1}\right.$, Table 4).

Beneath the three pingos emitting gas into the overlying water column, the seismic data revealed vertical zones of acoustic blanking in the shallow subsurface (up to $\sim 150 \mathrm{~m}$ depth) and adjacent local high amplitude anomalies. In contrast, lower amplitude dipping reflectors and only a very narrow zone of weak acoustic blanking were observed underneath GHP5 (Fig. 6).

\section{Discussion}

Four gas hydrate pingo features within a $2 \mathrm{~km}^{2}$ area on the Arctic shelf were examined for this study. Split-beam echosounder data, collected over multiple years and seasons, revealed gas bubbles in the water column above three of the four GHPs, often reaching impressive heights of $100 \mathrm{~m}$ above the seafloor (Serov et al., 2017). The emitted gases are primarily methane of thermogenic origin, confirming that these GHPs (GHP1, GHP2, GHP3) represent highly active methane seep sites. Although gas emissions into the water column were not detected at GHP5, the presence of bacte-
Table 4. Sulfate flux rates measured in cores from GHP3 and GHP5.

\begin{tabular}{lcrr}
\hline $\begin{array}{l}\text { Core } \\
\text { number }\end{array}$ & $\begin{array}{c}\text { GHP } \\
\text { number }\end{array}$ & $\begin{array}{r}\text { Sulfate } \\
\text { flux } \\
\left(\mathrm{mole} \mathrm{m}^{-2} \text { day }^{-1}\right)\end{array}$ & $\begin{array}{r}\text { Depth } \\
\text { range for } \\
\text { measurements }(\mathrm{cm})\end{array}$ \\
\hline 911 & 3 & 2.08 & $15-74$ \\
1045 & 3 & 1.27 & $10-110$ \\
940 & 3 & 0.31 & $5-313$ \\
920 & 5 & 0.37 & $10-240$ \\
1048 & 5 & 0.12 & $10-324$ \\
1068 & 5 & 0.90 & $12-308$ \\
1069 & 5 & 0.58 & $8-206$ \\
1070 & 5 & 0.90 & $8-266$ \\
\hline
\end{tabular}

rial mats indicates that this pingo also exhibits seepage, and analyses indicate that it is also of thermogenic origin (Serov et al., 2017). Carbonate formations, including large slabs, were seen on all four pingos, suggestive of long-term seepage (Berndt et al., 2014; Crémière et al., 2016; Seabrook et al., 2018). In this study, imagery was used to unveil key attributes of these shallow water $(<400 \mathrm{~m})$ Arctic cold-seep megafaunal communities, and the large-scale distribution of chemosynthesis-based community members was linked to overall seepage patterns and subsurface features. Comparisons of features of shallow water Arctic cold seeps identified through the present study with other seep sites indicate major differences between cold-seep communities at high and low latitudes. We conclude by considering cold seeps within the larger perspective of the Arctic, both from an ecological and economic point of view.

\subsection{Community characteristics}

A total of 62 megafaunal taxa were identified at the pingo site, and on average 29 taxa were seen within a single mosaic or image transect. No major differences in taxonomic richness between individual pingos were seen, though the image transects containing siboglinid frenulate aggregations were much less even in terms of species abundances compared to the transects and mosaics which did not contain any frenulate aggregations (Table 3 ). This is clearly due to the extremely high abundance of frenulates (thousands of individuals), and with this group excluded, diversity indices of the various pingos are comparable. It should be noted that species richness counts, and even morphospecies richness counts, are considerably higher because, in certain cases, morphospecies were grouped together under a single category. In one instance, this larger level grouping even lumped two different phyla together (gastropod molluscs with hermit crab arthropods). Among the taxa list generated for the pingo site, cnidarians accounted for the largest number of taxa (18), followed by echinoderms (11) and then chordates (10). After the frenulates, Gersemia corals and spherical Thenea sponges were the next most numerous groups of animals. A few different 


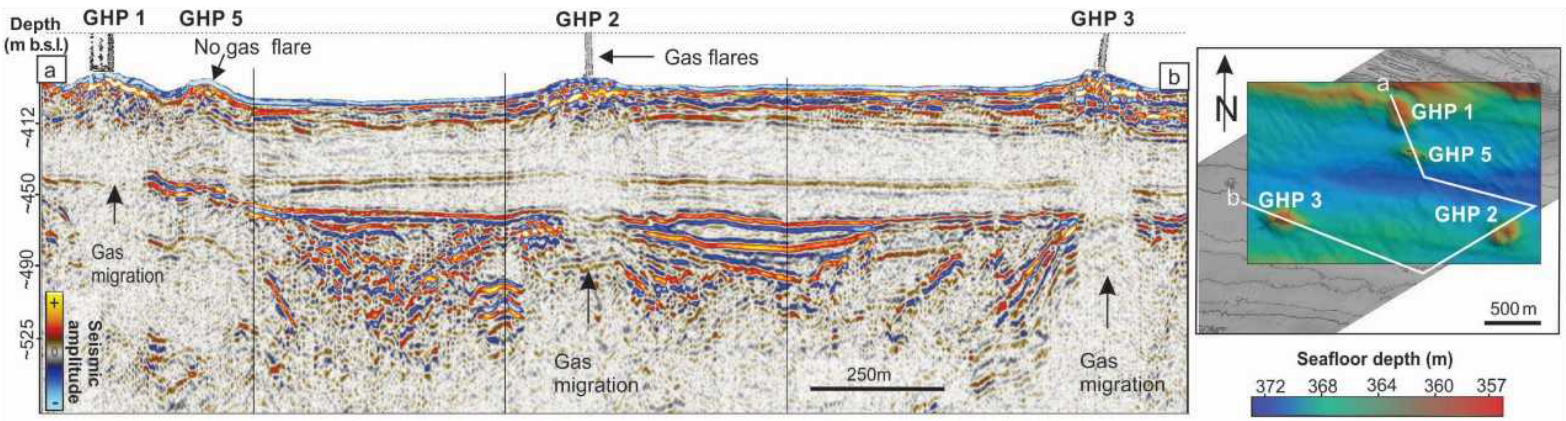

Figure 6. Seismic profile of the four study pingos. The transect for the seismic profile is shown in the map of the study site, starting near GHP1 (point a) and ending near GHP3 (point b). Zones of acoustic blanking beneath the three free-gas-emitting pingos are highlighted with arrows. This kind of blanking was not seen below GHP5.

types of commercial species were seen, including Atlantic cod (Gadus morhua), northern shrimp (Pandalus borealis), haddock (Melanogrammus aeglefinus) and Greenland halibut (Hippoglossoides platessoides). Only one chemosynthesisbased species was seen, the siboglinid frenulate worm, $O$. cf. haakonmosbiensis. This species is also the only animal seen in the images of the site that could possibly be a seepobligate species. However, the generalist lifestyle of frenulates (Hilário et al., 2011; Southward, 2000; Southward et al., 2005) and the debate around the consideration of $O$. haakonmosbiensis as a separate species from the fjord frenulate Oligobrachia webbi (Meunier et al., 2010) mean that it is possible that, despite the cold-seep setting, the entire visible megafaunal pingo community consists solely of background benthic species, regardless of whether community members are chemosynthesis based or conventionally heterotrophic. Nonetheless, the animals at the study site appear to take advantage of and utilize the seep environment and its inherent characteristics.

In some cases, such as for hard-substrate-dwelling animals like sponges or corals, the benefits of a seep system on the benthic landscape is evident: it provides hard settlement surfaces, in the form of authigenic carbonates, in a predominantly soft sediment seafloor (Becker et al., 2009; Cordes et al., 2008; Levin et al., 2015). The advantage of abundant hard settlement substrates likely corresponds with cnidarians and sponges being the most abundant and speciose of the phyla seen at the site. Mobile species such as $P$. borealis shrimp and ophiuroids were also often seen among carbonates, and for these taxa the advantage of these structures likely lies in the increase in habitat heterogeneity created by them, which can provide shelter or protection (Åström et al., 2017b).

Other taxa might make use of the other major advantage of the seep environment, i.e., autochthonous chemoautotrophic primary production, which, combined with detrital, photosynthetically derived material (Sibuet and Olu-Le Roy, 2002), could lead to a high food supply at the pingo site. Indeed, certain taxa appeared to show affinities for chemosynthesis-based seep habitats, i.e., the frenulate worms and bacterial mats, both of which constitute the base of the local food chain. One of the snow crabs, for example, was seen grazing among the bacterial mats (Fig. 7). Importantly, this is likely the first record of such behavior in snow crabs, since they are not normally associated with cold seeps. Other crabs in the Majidae family have been seen at cold seeps (Martin and Haney, 2005) and are considered to either be grazers of filamentous bacteria or predators of vesicomyid clams (Barry et al., 1996). While the chemosynthetic members themselves could serve as a food source for certain animals, the combination of high primary production and settlement surfaces together could lead to higher food availability for other, and particularly higher order, consumers. Siboglinid worms, including frenulates, are known to enhance local infaunal diversity and density (Bernardino et al., 2012), and samples from the pingo study site contained numerous instances of foraminifera, polychaetes and caprellids adhering to the tubes of the worms. Pycnogonids were largely associated with frenulate worms, and mosaics or image transects without frenulates contained the lowest numbers of pycnogonids. $P$. borealis individuals were often present among bacterial mats and frenulates, in addition to often being in and around carbonate concretions. Since these animals are known to be predators and scavengers (Arnaud and Bamber, 1988; Bergström, 2000), the advantage of the frenulate habitat is likely enhanced prey availability. Similarly, certain gastropods were seen perched atop carbonate structures and it is unlikely that the hardness of the concretions or their sheltering properties are of particular significance for this shelled group of animals. Rather, it is probably the dense colonization of these structures by various animals that accounts for this association with carbonates, since the observed gastropods likely also have predatory or scavenging feeding styles (Aguzzi et al., 2012).

One of the most numerically abundant taxa at the site was the spherical sponge, Thenea sp. (Fig. 8b) Individuals did not appear to associate with any seep-specific features or habitats. Instead, they were seen on soft sediment and this genus is known to use fascicles of spicules to anchor itself 

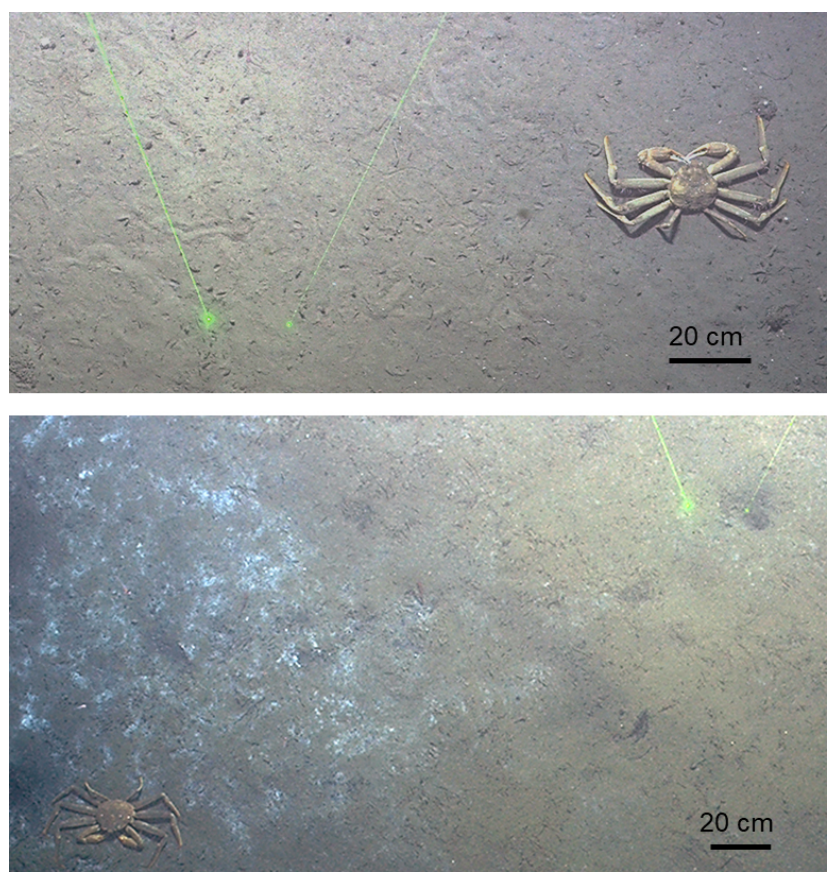

Figure 7. Snow crabs (Chionoecetes opilio) seen at GHP3. Note the presence of the crab within a microbial mat in the lower image.

into sediment and mud (Vacelet and Donadey, 1977). Similarly, the onuphid polychaete Nothria conchylega was seen in large numbers at the study site (Table 1), but did not display an affinity for any seep habitat such as carbonates, bacterial mats or frenulate worms. Both Thenea sponges and $N$. conchylega are common benthic taxa and their quantities at the study site could simply be due to the site falling within their natural distributional range. Alternatively, the local productivity of the seep system could be beneficial for them and account for their high numbers at the study site (since the increased availability of hard substrate is of no particular consequence to these soft-sediment-dwelling animals). Indeed spherical sponges (Stelleta and Pseudosuberites genera) occur in high abundances in New Zealand seeps on the Hikurangi Margin, where they are associated with sulfidic sediments and areas of active seepage (Baco et al., 2010; Bowden et al., 2013; Thurber et al., 2010). Similarly, the onuphid polychaete Hyalinoecia artifex has been observed at US Atlantic seeps, where they maintain a carnivorous, epibenthic lifestyle, crawling and dragging their tubes along the seafloor (Meyer et al., 2016). Trails in the sediment were seen behind $N$. conchylega individuals in this study, which is evidence for crawling behavior on the seafloor of this species as well (see Fig. 8a). Clearly visible trails associated with $N$. conchylega are of significance since this species has been postulated to exhibit crawling behavior (Budaeva and Paxton, 2013; Hayward and Ryland, 1995), but to our knowledge, this is the first time such behavior has actually been documented.
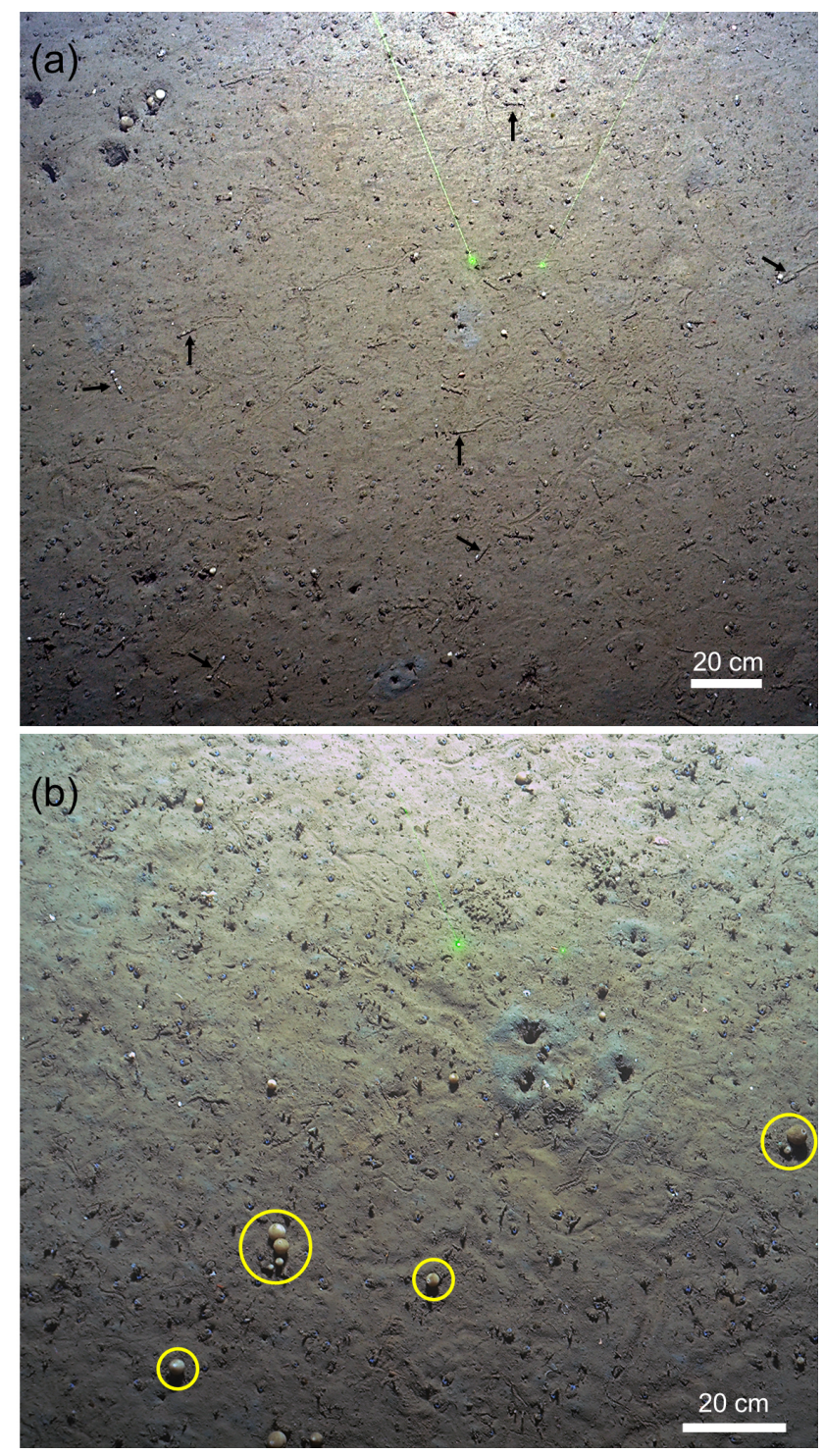

Figure 8. (a) Examples of the onuphid worm, Nothria conchylega (a few individuals are highlighted with black arrows). Note trails in the sediment behind the onuphids, indicating they crawl on the seafloor surface. (b) Examples of Thenea sponges (possibly Thenea valdiviae). A few individuals are circled in yellow.

Other than food and substrate availability, another possible advantage of the seep environment that could be capitalized upon by the resident animals is a diverse and abundant microbial community, including members that are less abundant in background sediment. For example, seep sediment is dominated by sulfate-reducing and sulfur-oxidizing bacteria as well as methanotrophs, whereas seafloor sediment from nonseep areas is dominated by more cosmopolitan bacteria (Seabrook et al., 2018). Spherical Pseudosuberites sponges from New Zealand seeps are even hypothesized to be chemoautotrophic (Thurber et al., 2010). In general, sponges and corals tend to have a highly diverse bacterial mi- 
crobiome (Blackall et al., 2015; Bourne et al., 2016; Vacelet and Donadey, 1977). The dominant members of coral microbiomes are proteobacteria (particularly gamma and alpha) (Bourne et al., 2016; Littman et al., 2009; Rohwer et al., 2002), and gammaproteobacteria are known to be common members of seep sediment communities (Valentine, 2011), including at HMMV (Lösekann et al., 2007; Niemann et al., 2006). Archaea, including anaerobic methanotrophs and nitrate reducers, are also known to associate with corals ( $\mathrm{Si}$ boni et al., 2008; Wegley et al., 2004), and archaeal anaerobic methanotrophs (known as ANMEs) are key players in the AOM that is so fundamental to seep geochemistry (Boetius and Wenzhöfer, 2013; Knittel et al., 2005; Knittel and Boetius, 2009). Therefore, the pingo seeps could be beneficial for certain species that associate with bacteria because they provide access and exposure to a more diverse array of bacterial strains than is present in the nonseep benthic seafloor.

\subsection{Factors controlling the distribution of chemosynthesis-based community members (frenulates)}

We hypothesized that the lack of free gas ebullition at GHP5 was representative of this pingo being substantially different from the other three, in terms of both abiotic and biotic features. As hypothesized, community analysis based on data from the georeferenced images and mosaics indicate that the communities on the three free-gas-emitting GHPs differ, and cluster separately from those on GHP5 (Fig. 3). The TC25 transect over GHP3 appeared to be an exception, because it clustered with the GHP5 communities (Fig. 3). However, no frenulate aggregations were visible in this particular transect, a feature shared with the GHP5 mosaics. Since frenulate abundances were in the order of thousands of individuals, community analyses were also conducted with them excluded which resulted in GHP5 communities forming a distinct group from the other pingo communities. Nonetheless, the most obvious difference between GHP5 communities and the communities on the other pingos was the absence of frenulate aggregations. This difference was further confirmed through various types of cores, scoop samples and extensive ROV-based surveys. GHP5 was surveyed with the ROV before mosaic-based imaging was conducted with the explicit purpose of locating siboglinid worms, since they were considered to be representative of locations with active seepage. Despite these efforts, no aggregations of these animals were seen. Furthermore, siboglinids were not recovered in any of the gravity cores taken from GHP5. Additionally, the site was revisited recently with a higher resolution tow cam and transects over pingo 5 failed to detect the presence of frenulate aggregations (Panieri et al., 2017). Combined, these results suggest that aggregations of siboglinids are truly absent from GHP5, as opposed to them simply not being present in the mosaics of GHP5, which covered more discrete areas than the transects over the other pingos.

The lack of frenulate aggregations from GHP5 has important ecological implications since they are the only confirmed chemosynthesis-based animal at the study site. All frenulates have obligate, nutritional symbiotic associations with bacterial endosymbionts (Fisher, 1990; Hilário et al., 2011; Southward, 1982; Southward et al., 2005), and molecular data and electron micrographs suggest that thiotrophy is the dominant metabolic mode for symbionts of $O$. haakonmosbiensis (Lösekann et al., 2008; Pimenov et al., 2000). Thus we expected sediment sulfide concentrations at GHP5 to be lower than those at the other pingos, and too low to sustain the frenulate worms and their symbionts.

Contrary to our expectations, sediment sulfide concentrations at GHP5 were not lower in comparison to GHP3 (Fig. 3a). Sulfide (and sulfate) measurements were only possible in cores from GHP3 and GHP5, but due to the other similarities between GHP3 and the other free-gas-emitting pingos, we consider sulfide and sulfate profiles of GHP3 to be representative of conditions at GHP1 and GHP2 as well. The sulfide concentrations measured on GHP5 were at the millimolar level, which is likely not limiting with respect to supporting chemosynthesis-based fauna of this size. Though the exact sulfide needs of frenulates and $O$. cf. haakonmosbiensis have not been quantified, significantly larger chemoautotrophic symbioses are known to be found in environments with lower in situ concentrations of dissolved sulfide (Decker et al., 2017; Podowski et al., 2010; Sarrazin et al., 1999; Sen et al., 2013; Urcuyo et al., 2003). Therefore, the sediment at GHP5 contains more than enough sulfide to theoretically support $O$. cf. haakonmosbiensis, and yet large aggregations of the species are absent from this pingo.

Therefore, other factors likely account for the absence of frenulate aggregations on GHP5, overriding the advantage of an abundant energy source to this chemo-obligate worm. Colonization being inhibited by an inadequate larval supply can be eliminated because GHP5 is in the vicinity of the other three pingos. In experiments conducted on Siboglinum fiordicum frenulates, only larvae reared in containers with $10 \mathrm{~cm}$ of sediment grew well (Bakke, 1974), and in general, soft sediment is considered the preferred substrate of frenulates (Southward, 1999, 2000; Southward et al., 2005). Soft sediment is the primary sediment type at GHP5, and therefore a lack of suitable substrate does not explain the absence of frenulate aggregations at GHP5 either. The settlement cues for frenulates are not known, but methane and sulfide have been hypothesized to serve as such cues for seep animals in general (Cordes et al., 2010). Only sulfide has been tested experimentally, and was shown to positively correlate with settlement of seep-associated polychaetes (Levin et al., 2006). We were unable to detect sulfide in the bottom water at any of the study pingos (Fig. 3). However, our detection limit for sulfide was $40 \mu \mathrm{M}$ and frenulate larvae could potentially detect or be attracted to concentrations lower than this. 
Nonetheless, it is unlikely that GHP5 is deficient with respect to sulfide in the bottom water, in comparison with the other pingos, since GHP sediment sulfide profiles were similar to those from the other pingos. Additionally, bacterial mats that rely on sulfide reaching the sediment-water interface, were seen at GHP5, as they were seen at the other pingos.

Nevertheless, GHP5 does differ from the pingos in other respects. The geophysical setting of GHP5 was different, with clear zones of acoustic blanking below GHPs 1-3 absent beneath GHP5 (Fig. 5). Such regions of acoustic wipeouts are interpreted as gas-saturated sediment. Therefore, a subsurface gas reservoir is likely connected to GHPs $1-3$, which allows for advection of gas through the sediment and up into the water column. The absence of acoustic blanking, except in the form of a narrow zone of weak blanking underneath GHP5, suggests reduced subsurface gas transport, or alternatively, a deeper barrier for upward gas migration, and subsequently lower upward methane flux. In accordance with this, sediment methane concentrations were lower at GHP5 in comparison to the other pingos (Fig. 3b), and gas hydrates were not recovered from GHP5, though they were recovered in cores from the other pingos. Correspondingly, AOM rates would be expected to be lower at GHP5. Comparative AOM rates are not available for the different study pingos, but AOM occurs in concert with sulfate reduction, and therefore sulfate fluxes can be used to make inferences about AOM rates. Sulfate reduction can and does take place in the absence of AOM as well (Dale et al., 2008; Hong et al., 2014; Wallmann et al., 2006), and therefore it is important to differentiate between AOM and the breakdown of organic material as being the process that consumes sulfate in a specific system. This can be done by utilizing the stoichiometric relationship of the two sulfate reduction pathways (Claypool et al., 2006; Suess and Whiticar, 1989), specifically, by measuring the ratio of increase in DIC to the decrease in sulfate. A 2:1 ratio is typical when sulfate is consumed through the anaerobic breakdown of organic matter. This ratio changes to $1: 1$ when sulfate reduction is linked to AOM (Masuzawa et al., 1992). Though some of the cores displayed values close to the $2: 1$ mark at the shallower depths of the sediment, deeper into the sediment this ratio changes and approaches the $1: 1$ correspondence. In most cores, the ratio of DIC to sulfate consumption was found to be close to $1: 1$ regardless of depth (both GHP5 and GHP3). The one exception was core 1048 from GHP5, for which almost all values were closer to the $2: 1$ ratio. These results indicate that at both pingos 3 and 5 , sulfate consumption is linked primarily to AOM, particularly in deeper sediment. With the exception of core 940 (which was on the periphery of GHP3), all the cores from GHP5 exhibited lower sulfate flux rates than those at GHP3 (Table 4). Therefore, our data suggest that AOM rates are lower within GHP5, compared to the other pingos.

Lower AOM rates would result in lower rates of generation of two important products: hydrogen sulfide and bicarbonate (Boetius and Wenzhöfer, 2013; Knittel et al., 2005).
Constant replenishment of sulfide, or a fresh supply, i.e., high sulfide fluxes, might be more important for the frenulate worms than simply high concentrations in the sediment (Dubilier et al., 2008). Additionally, the generation of bicarbonate ions might be important for these worms. Because of the carbon fixation activities of their symbionts, frenulates need inorganic carbon, and indeed, RuBisCo coding genes have been found in $O$. haakonmosbiensis (Lösekann et al., 2008). Lösekann et al. (2008) hypothesized that $O$. haakonmosbiensis uses DIC produced either by AOM or the aerobic oxidation of methane. This hypothesis was put forward to explain the extremely negative carbon isotope signatures in O. haakonmosbiensis biomarker lipids measured by the authors and by Gebruk et al. (2003), values that had never before been measured in thiotrophic symbioses and which cannot be explained by chemoautotrophic carbon fixation alone, but can be explained by the worms incorporating isotopically light DIC produced by sediment microbes.

The authors further suggested that assimilation of microbial dissolved organic carbon (DOC) by the worms could also account for the depleted carbon isotope values. In fact, frenulates differ from other chemosymbiotic siboglinids, such as vestimentiferans, in that they appear to supplement their symbiont-provided chemosynthetic diet with dissolved organic material (Southward et al., 1979, 1981; Southward and Southward, 1970). The larvae of Siboglinum fiordicum were seen, in laboratory experiments, to grow from the larval stage to the juvenile stage over the course of 13 months, in which time it only used food from yolk reserves and from the surrounding sediment (Bakke, 1977). Furthermore, Dando et al. (2008) noted that, in situ, the tubes of frenulates are often turned towards where there are locally high concentrations of reduced organic matter in the sediment.

The dual need for inorganic and organic carbon sources (plus thiotrophic chemoautotrophy) could mean that $O$. cf. haakonmosbiensis relies heavily on a highly active sediment methanotrophic microbial community. We propose that this, in addition to or in combination with high sulfide flux, is the overriding factor that limits or excludes $O$. cf. haakonmosbiensis from GHP5 despite high sulfide availability. At the free-gas-emitting GHPs, the large subsurface gas chimneys lead to constant seepage of methane, which in turn supports abundant methanotrophic microbes and microbial activity, such as AOM linked to sulfate reduction and sulfide production, thereby providing desirable conditions for $O$. cf. haakonmosbiensis. On the contrary, at GHP5, seepage of methane is low due to the lack of a subsurface gas chimney. The seismic data reveal enhanced reflectors below GHP5, which may indicate pockets of subsurface gas or gas hydrates and indeed, methane is still present in the sediment, but in lower concentrations. As a result, methanotrophic microbes are likely less abundant and methanotrophic activity is considerably lower, as evidenced by lower AOM linked sulfate flux rates. A smaller and less active microbial community could mean that GHP5 is deficient in the carbon compounds 
(either organic or inorganic, or both), required by the worms, and sulfide flux rates might be too low to sustain them as well. Further studies, with a focus on the microbial community and their activity in the sediment will be required to test this hypothesis, though early results indicate that the microbial community of GHP5 is significantly different from those at the other pingos and that ANMEs make up less of the total microbial community at GHP5 compared to the others (Klasek et al., 2018). Furthermore, at HMMV, high rates of sulfate reduction and AOM were measured and high numbers of anaerobic methanotrophs were found around the bases of O. haakonmosbiensis tubes (Lösekann et al., 2008; Niemann et al., 2006). Similarly, high sulfate fluxes were measured at the Beaufort Sea O. haakonmosbiensis site (sulfate concentration decreased from seawater values to $<0.1 \mathrm{mmol}$ within $0.5 \mathrm{~m}$ of the sediment) (Paull et al., 2015).

\subsection{Comparisons to other seep sites}

Few studies have been conducted at other seep sites around the world using imagery and photomosaics to characterize megafaunal communities. Among the few that do, most report substantially lower species and taxa counts compared to the 62 taxa seen (conservatively) in this study: Lessard Pilon et al. (2010) recorded 15 taxa at a Gulf of Mexico seep site (approx. $2000 \mathrm{~m}$ water depth) and 13 taxa were seen in the density study by Olu et al. (2009) at the western African Regab pockmark. In their review, Sibuet and Olu (1998) summarized macrofaunal and megafaunal species counts from all the known seep sites at the time (400 to $6000 \mathrm{~m}$ water depth) and found the highest such count to be 42, and on average to be 12. Bowden et al. (2013) on average saw 20 species per site among seeps off New Zealand on the Hikurangi Margin (depth range: $744-1120 \mathrm{~m}$ ), although species richness counts were related to the different numbers of images analyzed per site. However, Rybakova et al. (2013) counted 31 taxa at HMMV (water depth about $1200 \mathrm{~m}$ ) and Amon et al. (2017) found 36 morphospecies on average across four Caribbean seeps at water depths ranging from 998 to $1600 \mathrm{~m}$.

However, the high diversity at the pingo site is not completely unexpected, given the shallow (less than $400 \mathrm{~m}$ ) water depth at which it is located. In general, diversity and species richness at cold seeps tend to decrease with increasing water depths (Sibuet and Olu, 1998). This usually applies to symbiont-containing species as well, so that shallow seeps have more symbiont-containing species than deeper seeps (Sibuet and Olu, 1998). The pingo site could represent a major deviation from this general trend, since so far only one chemosynthesis-based, symbiont-containing species has been confirmed at this site. Details on the infaunal community composition is currently being compiled, but across the $200+$ taxa seen, only 4 taxa (thyasirid bivalves) were encountered that could potentially contain symbiotic bacteria. Additionally, the spherical Thenea sponges at the site could contain symbionts, but even if that were the case, it is un- likely that the numbers of symbiont-containing species at the study site would rival the numbers (10-15 species) recorded at shallow sites. It should be noted, though, that only seep sites at water depths of $400 \mathrm{~m}$ or more were included in this review, and therefore shallow in this context nonetheless refers to sites often considered the deep sea. In fact, Dando (2010) noted the opposite trend in shallower seeps, i.e., a decrease in numbers of symbiotic species with decreasing water depths. This particular review also does not cover sites at water depths of the study site: it focuses specifically on seeps in water depths of $200 \mathrm{~m}$ or less. Sahling et al. (2003) examined depth-related trends in seeps along the Sakhalin shelf in the Sea of Okhotsk along a depth gradient of 160 to $1600 \mathrm{~m}$ and observed similar patterns to Dando (2010). These studies and our results illustrate that the relationship between depth and numbers of symbiontcontaining species at cold seeps is yet to be resolved. It is possible that at least two switching points exist: the shallowest sites have very few symbiont-containing species but at some point, possibly $400-500 \mathrm{~m}$, the numbers of symbiontcontaining species rapidly increases and reaches a maximum, after which deeper sites again see a drop in the numbers of symbiont-containing species. More studies on seeps at intermediate depths, such as those on continental shelves like the present study site, will be required to fully explore these trends.

Shallow seeps tend to be populated by a subset of the local, background benthic community (Dando, 2010), and this appears to be true for the pingo study site as well. At the megafaunal scale, $O$. cf. haakonmosbiensis appears to be the only possible exception and potential seep-obligate species, although Smirnov (2014) reports $O$. haakonmosbiensis from a muddy bottom site in the Laptev Sea, without any mention of it being a seep site (and furthermore, O. haakonmosbiensis might not be separate from $O$. webbi, which has been found in fjords). Background fauna and frenulates have also been observed at other Arctic seep sites, such as pockmarks on the Vestnesa Ridge ( Aström et al., 2017b) in the Barents Sea and mud volcanoes in the Beaufort Sea (Paull et al., 2015). At HMMV as well, the community conforms to this basic structure, with the addition of the chemosynthesis-based monoliferan worm, Sclerolinum contortum (Gebruk et al., 2003; Lösekann et al., 2008). These seeps all vary considerably in terms of water depth: $380 \mathrm{~m}$ at the pingo site, $282-740 \mathrm{~m}$ for the Beaufort Sea pockmarks, and $\sim 1200 \mathrm{~m}$ at both Vestnesa and HMMV. This indicates that in the Arctic, regardless of depth, soft-sediment seeps tend to have similar overall community structure of chemosynthesis-based siboglinids and background taxa. There is no transition to communities dominated by large, chemosymbiotic seep fauna such as vestimentiferan tube worms, vesicomyid clams and bathymodioline mussels, seen at about $400 \mathrm{~m}$ in seeps at lower latitudes (Sahling et al., 2003). Intriguingly, this separation between Arctic seeps and seeps in other parts of the world with respect to large chemosymbiotic species is likely only 
a modern trend. The shells of large-bodied chemosymbiotic bivalves (thyasirids and vesicomyids) have been recovered in cores from the pingo study site (Åström et al., 2017a), Vestnesa Ridge (Ambrose et al., 2015; Hansen et al., 2017; Sztybor and Rasmussen, 2017) and methane seep deposits on the Gakkel Ridge (Kim et al., 2006) and in the Laptev Sea (Sirenko et al., 1995). Shells from the pingo site have been estimated to be up to 7000-14000 years old (M. Carroll, unpublished data), and based on the Vestnesa and Gakkel Ridge samples, the extinction event for these animals has been estimated to have taken place around 15000 years ago (Ambrose et al., 2015; Hansen et al., 2017; Kim et al., 2006; Sztybor and Rasmussen, 2017). This coincides with deglaciation following the Heinrich H1 cold event and the accompanying environmental changes, including extensive releases of methane such as is hypothesized to have created the pingos at the study site (Serov et al., 2017). This could have led to the local extinction of large chemosymbiotic bivalves in the Arctic. Since recolonization has not taken place despite Atlantic water inflow (and at least Vestnesa and the pingo site fall within the path of the North Atlantic current), the changes that triggered the presumed demise of the Arctic chemosynthetic bivalves likely persist today. Sztybor and Rasmussen (2017) proposed the drop of bottom water temperatures to subzero levels at Vestnesa to be the explanatory factor. However, bottom water temperatures are about $2{ }^{\circ} \mathrm{C}$ on average at the pingo site and mean annual bottom water temperature at the Beaufort Sea pockmarks is $0.2^{\circ} \mathrm{C}$ (although temperatures as low as $-1.1^{\circ} \mathrm{C}$ were also recorded, Paull et al., 2015). Vesicomyids of the genus Isorropodon have also been sampled at the Nyegga seep site in the Norwegian Sea (Krylova et al., 2011), where bottom water temperatures are $-0.7^{\circ} \mathrm{C}$ (Portnova et al., 2014). These data make it difficult to use modern bottom water thermal regimes as a sufficient reason to explain the death and subsequent lack of recolonization of large chemosynthetic bivalves in the Arctic, although it could play a role. The precise causes for the disappearance and continued absence of large, chemosynthetic bivalves in the Arctic are still unclear. Nonetheless, based on the existing data, Arctic seeps appear to form a distinct biogeographical entity, exhibiting the same general seep community structure, but one that is different from seep communities in other parts of the world.

Another way in which the pingo site appears to deviate from generalized seep trends relative to lower latitude seeps is with respect to the factors that promote successional progression of the communities. The presence of carbonate slabs on GHP5 indicates that this site could have experienced higher levels of seepage activity in the past and in fact, based on detailed geochemical and geophysical analyses, Hong et al. (2018) concluded that this pingo represents a later stage in the geophysical history of these features. Therefore, it is likely that the community on this pingo also represents a later stage in the succession of the pingo seep communities. At present, aggregations of the chemoau- totrophic frenulate worms no longer exist, but the products of seepage, such as carbonate rocks, provide settlement substrates, making this community diverse and densely colonized. This is similar to what has been observed or predicted at lower latitude seeps, where carbonates and the tubes of vestimentiferans provide a substrate for hard bottomed animals such as sponges or cnidarians (Bergquist et al., 2003; Bowden et al., 2013; Cordes et al., 2005). The key difference is that in these studies and models of succession in lower latitude seeps, a major driving force from an active to a senescent or background-fauna-dominated community is a cessation or displacement of fluid flow, often accompanied by a decrease in sediment sulfide concentrations. However, the sediment at GHP5 does not have lower sediment sulfide concentrations than the sediment hosting the earlier successional communities on the free-gas-emitting pingos (although methane seepage has likely decreased or even ceased due to the exhaustion of the subsurface gas chimney). As discussed above, lower latitude seeps at comparable or greater depths are characterized by the presence of more than one type of large-bodied chemoautotrophic faunal group, each with different geochemical needs and niches. This is not true for the study site, where so far $O$. cf. haakonmosbiensis alone makes up the entirety of the megafaunal chemoautotrophic community. Infaunal thyasirid bivalves could possibly expand the chemosymbiotic repertoire of the study site; however, only small-bodied species were found that usually only reached a maximum size of about $5 \mathrm{~mm}$ in length. Therefore these species are unlikely to be considered megafauna $(1 \mathrm{~cm}$ in maximum dimension is the lowest level at which animals have been considered megafauna) (Amon et al., 2017). This difference, of 1 , compared to multiple chemoautotrophic megafaunal species being present, could account for the pingo site deviating from the trend of successional progression at seeps, paralleling changes to sulfide concentration and availability. A highly limited chemosynthesisbased megafaunal community appears to be the norm at Arctic seep sites, and therefore the pattern of successional progression in the absence of depleted sulfide reserves observed at the pingo site, though currently quite unique, could be representative of the Arctic in general, although further studies are needed in order to confirm this.

\subsection{Arctic perspectives}

Among the diverse assemblages of background benthic species present at the pingo site are a number of commercially important species. Atlantic cod (Gadus morhua) and the northern shrimp (Pandalus borealis) were particularly numerous, but haddock (Melanogrammus aeglefinus) and various flat fishes such as Greenland halibut (Hippoglossoides platessoides) were also seen. In addition, two individuals of snow crab (Chionoecetes opilio) were seen in the images over GHP3 (Table 1, Fig. 7). Commercial species have been observed at seep sites around the world (Baco et al., 
2010; Bowden et al., 2013; Grupe et al., 2015; Higgs et al., 2016; Niemann et al., 2013; Sellanes et al., 2008) and the importance of methane seeps to local fisheries has been recently gaining attention (Levin et al., 2016). In at least two cases, diets with a significant chemosynthetic component have been established for commercial species (Higgs et al., 2016; Niemann et al., 2013). Additionally, seep- or site-specific characteristics (three-dimensional carbonate structures, proximity to oxygen minimum zones, chemical environments excluding predators or parasites) have been hypothesized to account for the enhanced densities of commercial fish species at seeps in comparison to nonseep environments (Levin et al., 2016; Sellanes et al., 2008). At the pingo site, no data currently exist on whether chemosynthesis-derived material constitutes any part of the diets of the observed commercial species, or which features of the seep environment draws them to the location. Nonetheless, species targeted for commercial fishing are abundant at the pingo site. Methane seeps have not been studied intensively in the Arctic and their potential contributions to the Norwegian fishing industry have never been explored. Our results, for the first time, indicate that methane seeps could function as a habitat for multiple economically important species.

Nearby background areas not affected by seepage were not imaged during this study, and therefore quantitative comparisons between the pingo seeps and the surrounding seafloor with respect to megafauna were not possible. However, the tow cam image transects covered some area outside and to the west of GHP3 (although bacterial mats were seen in this area, so it likely does not constitute a truly nonseep environment). Every individual of every visible taxon was not marked in this area, although the total number of taxa seen in this area was recorded. In total, 28 taxa were seen in this "non-pingo" area of $2330 \mathrm{~m}^{2}$, which amounts to 1.2 taxa per $100 \mathrm{~m}^{2}$. This is considerably lower than the richness counts recorded in the pingo mosaics and transects (average 4.1 species per $100 \mathrm{~m}^{2}$, Table 3 ). Density and abundance data could not be compared with the pingos because these data were not compiled for this area, but the pingos appeared to be more densely colonized than the nonseep area. Qualitative comparisons of faunal abundances and a single comparison of richness counts are not sufficient for drawing robust conclusions about the differences between pingo-seep communities and the surrounding seabed. Nonetheless, our results suggest the possibility of the pingos creating a biomass and diversity hotspot on the seafloor with respect to megafauna. In fact, this has been suggested (despite a similar absence of quantitative data) for the Concepción seep on the continental slope off Chile (Sellanes et al., 2008), and for HMMV, where Gebruk et al. (2003) noted that the background community appeared to be much "poorer" than the HMMV community. Åström et al. (2017b) also found higher species richness, biomass and diversity at Vestnesa Ridge seep sites in comparison to nonseep sites.
Therefore, seep sites such as the studied pingos could hold ecological significance. The Norwegian government has prioritized protection and mapping of the shelf and areas where coral, sponge, sea pen or other communities of high importance to the Barents Sea-Lofoten ecosystem (Norwegian Ministry of the Environment, 2010). Our results indicate that methane seeps could constitute one of these communities important to the ecology of the Barents Sea and the Arctic. Sites with gas hydrate reservoirs and seafloor methane emissions appear to be quite extensive along the Arctic shelf in the Barents Sea (Bünz et al., 2012; Sahling et al., 2014; Vadakkepuliyambatta, 2014; Westbrook et al., 2009), and therefore the impact of methane seeps on the larger benthic community could be widespread. However, Arctic shelf seep communities have not been systematically mapped, nor has their effect on seabed ecosystem dynamics been assessed, and therefore we suggest their inclusion in current monitoring, mapping and conservation efforts.

In the Arctic, recognition of and maintenance of diversity hotspots is particularly relevant, because Arctic communities are experiencing substantial disruptions such as species replacements or trophic shifts due to the northward range shifts of many subarctic or temperate species (Degen et al., 2016; Johannesen et al., 2012; Wassmann et al., 2011). It is debatable whether true Arctic biodiversity hotspots exist at all since the meaning of the term sensu stricto refers to areas with high concentrations of endemic species (Myers et al., 2000) and relatively few species are considered as being endemic to the Arctic (Barry et al., 2013). Nonetheless, certain locations in the Arctic do tend to contain elevated numbers of "true" Arctic species (Barry et al., 2013), and the diversity of the pingo site suggests that shelf cold seeps could fall under this category. Under most circumstances (i.e., in other parts of the world, at lower latitudes), one would not expect a seep site to be affected by the arrival of new species to the surrounding region, because the new arrivals would not be considered capable of successfully establishing themselves within the specialized seep environment. However, the community at the pingos does not contain specialized seep inhabitants and rather consists almost entirely of background benthic species. Furthermore, snow crabs were seen at the pingo site, even grazing on a bacterial mat, and this species has only been seen in the Barents Sea since 1996 (Kuzmin et al., 1998, 1999) and has spread to the northwest, reaching the western Spitsbergen fjords in 2017 (Paul Renaud, personal communication, 2017). The presence of snow crabs at the site indicates that species new to the area are capable of establishing themselves at the site, which suggests that these communities could experience the same types of upheavals documented at benthic sites along the path of northward migration of southern latitude species (Cochrane et al., 2009; Johannesen et al., 2012; Węsławski et al., 2011).

In short, our results indicate that the pingo study site and by extension other shelf seeps could constitute important habitats for multiple commercial species, possibly serve as 
biomass and diversity hotspots on the seafloor, and could be threatened by climate-change-induced ecological disturbances. Therefore, it is crucial that benthic mapping efforts and long-term monitoring projects proposed to understand the response of a changing Barents Sea (Barry et al., 2013; Jørgensen et al., 2015) take shelf seep communities into account as well. Since seeps are long-lived systems whose effect on the benthos can extend beyond the lifespan of seepage activity itself (Bowden et al., 2013; Cordes et al., 2008; Levin et al., 2016), careful management policies will need to be drafted, in order to successfully maintain the juxtaposition between maintenance of the seep habitat and its economic exploitation.

\section{Conclusions}

Studies focused on the biology and ecology of Arctic cold seeps are rare. Therefore, the natural laboratory conditions of multiple pingos within a limited spatial extent at the study site provided an unprecedented opportunity to study the response of Arctic seep communities, and particularly chemosynthetic members, to variable physical factors. Our results show that despite the likelihood of sulfide being the dominant energy source, concentrations of sulfide in the sediment do not necessarily correlate with the presence or absence of aggregations of the only confirmed chemosynthesisbased animal at the site, $O$. cf. haakonmosbiensis frenulates. We hypothesize that high sulfide flux and/or dissolved inorganic or organic carbon produced by microbial methanotrophic activity in the sediment constitute the major carbon source for these worms, and small microbial communities and low methanotrophic activity in the sediment limit the presence of these worms even when sulfide is abundant. Oligobrachia worms are ubiquitous across Arctic seeps and this is the first time that its distribution could be correlated with variable physical conditions. Overall, the pingo communities are characterized by a diversity of background species and a lack of seep-obligate species, both of which are likely a function of the location of the study site on the shallow (less than $400 \mathrm{~m}$ ) shelf. This study is the first to document seafloor crawling behavior of Nothria conchylega onuphid worms, behavior which has only been hypothesized before. Commercially important fish and crustacean species were seen in large numbers and, surprising for a seep site, a species that is relatively new to this area (the snow crab) was seen grazing among bacterial mats. Further investigation of the pingo site and others like it is important to understand shallow water and shelf cold seeps, their effect on the benthos, and their responses or possible susceptibility to a changing and warming Arctic.
Data availability. The data are stored at the CAGE Centre for Arctic Gas Hydrate, Environment and Climate's data repository and requests for access should be directed to cage_data@list.uit.no. 


\section{Appendix A}

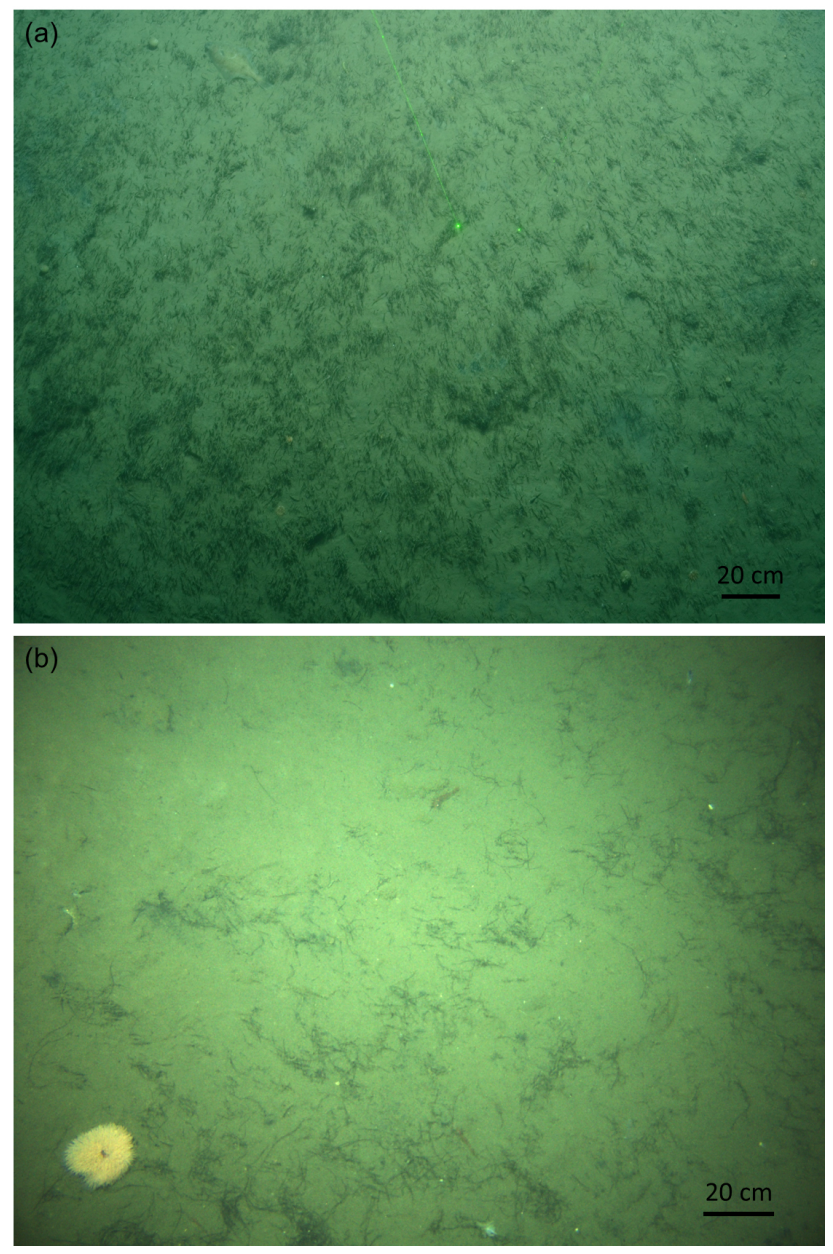

Figure A1. Example of aggregations of Oligobrachia cf. haakonmosbiensis frenulate worms seen in the images used in this study. The worms are visible as dark patches in the sediment. Individual worms could not be differentiated; however, aggregations are clearly visible. (a) Raw tow cam image within a frenulate aggregation. Note also the Thenea sponges and the Greenland halibut in the image. (b) Raw image from the ROV stereo camera in which patches of Oligobrachia are visible, along with shrimp and a pom pom anemone. 
Author contributions. AS constructed the mosaics, marked animals and conducted the community analyses. EÅ identified most species and taxa. WLH analyzed the geochemical data and MW and AP analyzed the geophysical data. PS quantified methane concentrations. All authors actively engaged in scientific discussions regarding the study and were involved in writing the paper.

Competing interests. The authors declare that they have no conflict of interest.

Acknowledgements. We would like to thank the captain and crew of Helmer Hanssen, the chief scientists (Stefan Bünz and Giuliana Panieri) and the scientific teams of the cruises from which data for this project were gathered. We are deeply indebted to the tow cam team (Daniel Fornari and Gregory Kurras) and the ROV team (Martin Ludvigsen, Frode Volden, Stein Nornes and Pedro de la Torre), without whom this project would not have been possible. We are also very thankful to Bjørn Runar Olsen and Roy Robertsen, for their patience and expertise with problem solving at sea, Bo Krogh, for helping with the navigation data, and Steinar Iversen for helping with cruise preparations. Hans Tore Rapp, Nataliya Budaeva, Mari Eilertsen, Jon Kongsrud and Irina Zhulay helped with species' identifications, and provided information on their biology, for which we are extremely grateful. Friederike Gründger and Matteus Lindgren analyzed and quantified methane concentrations in cores from 2016. We would also like to thank Paul Dando, Karine Olu, Ann Andersen and an anonymous reviewer for discussions that helped refine this paper, and Diva Amon, Scott Klasek, Ashley Rowden and David Bowden for sharing details of their datasets with us. This study was funded through the Centre for Arctic Gas Hydrate, Environment and Climate (CAGE) and the Research Council of Norway through its Centres of Excellence scheme, project number 223259.

Edited by: Jack Middelburg

Reviewed by: Paul Dando and one anonymous referee

\section{References}

Aguzzi, J., Jamieson, A. J., Fujii, T., Sbragaglia, V., Costa, C., Menesatti, P., and Fujiwara, Y.: Shifting feeding behaviour of deep-sea buccinid gastropods at natural and simulated food falls, Mar. Ecol. Prog. Ser., 458, 247-253, https://doi.org/10.3354/meps09758, 2012.

Ambrose, W. G., Panieri, G., Schneider, A., Plaza-Faverola, A., Carroll, M. L., Åström, E. K. L., Locke, W. L., and Carroll, J.: Bivalve shell horizons in seafloor pockmarks of the last glacial-interglacial transition: a thousand years of methane emissions in the Arctic Ocean: Past Arctic Ocean Methane Emissions, Geochem. Geophys. Geosys., 16, 41084129, https://doi.org/10.1002/2015GC005980, 2015.

Amon, D. J., Gobin, J., Van Dover, C. L., Levin, L. A., Marsh, L., and Raineault, N. A.: Characterization of Methane-Seep Communities in a Deep-Sea Area Designated for Oil and Natural Gas Exploitation Off Trinidad and Tobago, Front. Mar. Sci., 4, 342, https://doi.org/10.3389/fmars.2017.00342, 2017.
Andreassen, K., Hubbard, A., Winsborrow, M., Patton, H., Vadakkepuliyambatta, S., Plaza-Faverola, A., Gudlaugsson, E., Serov, P., Deryabin, A., Mattingsdal, R., Mienert, J., and Bünz, S.: Massive blow-out craters formed by hydrate-controlled methane expulsion from the Arctic seafloor, Science, 356, 948953, https://doi.org/10.1126/science.aal4500, 2017.

Arnaud, F. and Bamber, R. N.: The Biology of Pycnogonida, in: Advances in Marine Biology, vol. 24, edited by: Blaxter, J. H. S. and Southward, A. J., pp. 1-96, Academic Press, 1988.

Åström, E. K. L., Carroll Jr., M. L., Ambrose Jr., W. G., and Carroll, M. J.: Arctic cold seeps in marine methane hydrate environments: impacts on shelf macrobenthic community structure offshore Svalbard, Mar. Ecol. Prog. Ser., 552, 1-18, https://doi.org/10.3354/meps11773, 2016.

Åström, E. K. L., Oliver, P. G., and Carroll, M. L.: A new genus and two new species of Thyasiridae associated with methane seeps off Svalbard, Arctic Ocean, Mar. Biol. Res., 13, 402-416, https://doi.org/10.1080/17451000.2016.1272699, 2017a.

Åström, E. K. L., Carroll, M. L., Ambrose, W. G., Sen, A., Silyakova, A., and Carroll, J.: Methane cold seeps as biological oases in the high-Arctic deep sea, Limnol. Oceanogr., 23 pp., https://doi.org/10.1002/lno.10732, 2017b.

Baco, A. R., Rowden, A. A., Levin, L. A., Smith, C. R., and Bowden, D. A.: Initial characterization of cold seep faunal communities on the New Zealand Hikurangi margin, Mar. Geol., 272, 251-259, https://doi.org/10.1016/j.margeo.2009.06.015, 2010.

Bakke, T.: Settling of the larvae of Siboglinum fiordicum WEBB (Pogonophora) in the laboratory, Sarsia, 56, 57-70, https://doi.org/10.1080/00364827.1974.10411262, 1974.

Bakke, T.: Development of Siboglinum fiordicum Webb (Pogonophora) after metamorphosis, Sarsia, 63, 65-73, https://doi.org/10.1080/00364827.1977.10411323, 1977.

Barry, J. P., Gary Greene, H., Orange, D. L., Baxter, C. H., Robison, B. H., Kochevar, R. E., Nybakken, J. W., Reed, D. L., and McHugh, C. M.: Biologic and geologic characteristics of cold seeps in Monterey Bay, California, Deep-Sea Res. Pt. I, 43, 1739-1762, https://doi.org/10.1016/S0967-0637(96)00075$1,1996$.

Barry, T., Berteaux, D., and Bültmann, H.: Arctic Biodiversity Assessment: status and trends in Arcitc biodiversity, The Conservation of Arctic Flora and Fauna, Akureyri, Iceland, 2013.

Becker, E. L., Cordes, E. E., Macko, S. A., and Fisher, C. R.: Importance of seep primary production to Lophelia pertusa and associated fauna in the Gulf of Mexico, Deep-Sea Res. Pt. I, 56, 786-800, 2009.

Bergquist, D. C., Andras, J. P., McNelis, T., Howlett, S., Van Horn, M. J., and Fisher, C. R.: Succession in Gulf of Mexico Cold Seep Vestimentiferan Aggregations: The Importance of Spatial Variability, Mar. Ecol., 24, 31-44, https://doi.org/10.1046/j.14390485.2003.03800.x, 2003.

Bergström, B. I.: The biology of Pandalus, in Advances in Marine Biology, vol. 38, 55-245, Academic Press, Elsevier, 2000.

Bernardino, A. F., Levin, L. A., Thurber, A. R., and Smith, C. R.: Comparative Composition, Diversity and Trophic Ecology of Sediment Macrofauna at Vents, Seeps and Organic Falls, PloS One, 7, e33515, https://doi.org/10.1371/journal.pone.0033515, 2012.

Berndt, C., Feseker, T., Treude, T., Krastel, S., Liebetrau, V., Niemann, H., Bertics, V. J., Dumke, I., Dunnbier, K., Ferre, B., 
Graves, C., Gross, F., Hissmann, K., Huhnerbach, V., Krause, S., Lieser, K., Schauer, J., and Steinle, L.: Temporal constraints on hydrate-controlled methane seepage off Svalbard, Science, 343, 284-287, https://doi.org/10.1126/science.1246298, 2014.

Blackall, L. L., Wilson, B., and van Oppen, M. J. H.: Coral-the world's most diverse symbiotic ecosystem, Mol. Ecol., 24, 53305347, https://doi.org/10.1111/mec.13400, 2015.

Boetius, A. and Wenzhöfer, F.: Seafloor oxygen consumption fuelled by methane from cold seeps, Nat. Geosci., 6, 725-734, https://doi.org/10.1038/ngeo1926, 2013.

Bourne, D. G., Morrow, K. M., and Webster, N. S.: Insights into the Coral Microbiome: Underpinning the Health and Resilience of Reef Ecosystems, Annu. Rev. Microbiol., 70, 317-340, https://doi.org/10.1146/annurev-micro-102215-095440, 2016.

Bowden, D. A., Rowden, A. A., Thurber, A. R., Baco, A. R., Levin, L. A., and Smith, C. R.: Cold seep epifaunal communities on the Hikurangi margin, New Zealand: composition, succession, and vulnerability to human activities, PloS One, 8, e76869, https://doi.org/10.1371/journal.pone.0076869, 2013.

Brattegard, T.: A new species of multitentaculate pogonophora from northern Norway, Sarsia, 22, 55-63, https://doi.org/10.1080/00364827.1966.10409562, 1966.

Budaeva, N. and Paxton, H.: Nothria and Anchinothria (Annelida: Onuphidae) from eastern Australian waters, with a discussion of ontogenetic variation of diagnostic characters, J. Mar. Biol. Assoc. UK, 93, 1481-1502, https://doi.org/10.1017/S0025315412001956, 2013

Bünz, S., Polyanov, S., Vadakkepuliyambatta, S., Consolaro, C., and Mienert, J.: Active gas venting through hydrate-bearing sediments on the Vestnesa Ridge, offshore W-Svalbard, Mar. Geol., 332-334, 189-197, https://doi.org/10.1016/j.margeo.2012.09.012, 2012.

Cárdenas, P. and Rapp, H. T.: A review of Norwegian streptasterbearing Astrophorida (Porifera: Demospongiae: Tetractinellida), new records and a new species, Zootaxa, 3253, 1-53, 2012.

Carney, R. S., Haedrich, R. L., and Rowe, G. T.: Zonation of fauna in the deep sea, in: Deep-Sea Biology, edited by: G. T. Rowe, 97-122, Harvard University Press, Cambridge, MA, USA, 1983.

Carroll, J., Vikebø, F., Howell, D., Broch, O. J., Nepstad, R., Augustine, S., Skeie, G. M., Bast, R., and Juselius, J.: Assessing impacts of simulated oil spills on the Northeast Arctic cod fishery, Mar. Pollut. Bull., 126, 63-73, https://doi.org/10.1016/j.marpolbul.2017.10.069, 2018.

Chapman, R., Pohlman, J., Coffin, R., Chanton, J., and Lapham, L.: Thermogenic gas hydrates in the northern Cascadia margin, Eos Trans. Am. Geophys. Union, 85, 361-365, https://doi.org/10.1029/2004EO380001, 2004.

Claypool, G. E., Milkov, A. V., Lee, Y.-J., Torres, M. E., Borowski, W. S., and Tomaru, H.: Microbial methane generation and gas transport in shallow sediments of an accretionary complex, southern hydrate ridge (ODP Leg 204), offshore Oregon, USA, available at: http://agris.fao.org/agris-search/search. do?recordID=AV20120164748 (last access: 28 November 2017), 2006.

Cline, J. D.: Spectrophotometric determination of hydrogen sulfide in natural waters, Limnol. Oceanogr., 14, 454-458, 1969.

Cochrane, S. K. J., Denisenko, S. G., Renaud, P. E., Emblow, C. S., Ambrose, W. G., Ellingsen, I. H., and Skarðhamar, J.: Benthic macrofauna and productivity regimes in the Barents Sea -
Ecological implications in a changing Arctic, J. Sea Res., 61, 222-233, https://doi.org/10.1016/j.seares.2009.01.003, 2009.

Cordes, E. E., Hourdez, S., Predmore, B. L., Redding, M. L., and Fisher, C. R.: Succession of hydrocarbon seep communities associated with the long-lived foundation species Lamellibrachia luymesi, Mar. Ecol. Prog. Ser., 305, 17-29, https://doi.org/10.3354/meps305017, 2005.

Cordes, E. E., McGinley, M. P., Podowski, E. L., Becker, E. L., Lessard-Pilon, S., Viada, S. T., and Fisher, C. R.: Coral communities of the deep Gulf of Mexico, Deep-Sea Res. Pt. I, 55, 777-787, https://doi.org/10.1016/j.dsr.2008.03.005, 2008.

Cordes, E. E., Cunha, M. R., Galéron, J., Mora, C., Olu-Le Roy, K., Sibuet, M., Van Gaever, S., Vanreusel, A., and Levin, L. A.: The influence of geological, geochemical, and biogenic habitat heterogeneity on seep biodiversity: Seep habitat heterogeneity, Mar. Ecol., 31, 51-65, https://doi.org/10.1111/j.14390485.2009.00334.x, 2010.

Crémière, A., Lepland, A., Chand, S., Sahy, D., Condon, D. J., Noble, S. R., Martma, T., Thorsnes, T., Sauer, S., and Brunstad, H.: Timescales of methane seepage on the Norwegian margin following collapse of the Scandinavian Ice Sheet, Nat. Commun., 7, 11509, https://doi.org/10.1038/ncomms11509, 2016.

Dale, A. W., Regnier, P., Knab, N. J., Jørgensen, B. B., and Van Cappellen, P.: Anaerobic oxidation of methane (AOM) in marine sediments from the Skagerrak (Denmark): II. Reactiontransport modeling, Geochim. Cosmochim. Acta, 72, 2880 2894, https://doi.org/10.1016/j.gca.2007.11.039, 2008.

Dando, P. R.: Biological communities at marine shallow-water vent and seep sites, in: The Vent and Seep Biota, 333-378, Springer, Dordrecht, 2010.

Dando, P. R., Southward, A. J., Southward, E. C., Lamont, P., and Harvey, R.: Interactions between sediment chemistry and frenulate pogonophores (Annelida) in the north-east Atlantic, Deep-Sea Res. Pt. I, 55, 966-996, https://doi.org/10.1016/j.dsr.2008.04.002, 2008.

Danovaro, R.: Methods for the Study of Deep-Sea Sediments, Their Functioning and Biodiversity, CRC Press, 2009.

Decker, C., Zorn, N., Le Bruchec, J., Caprais, J. C., Potier, N., Leize-Wagner, E., Lallier, F. H., Olu, K., and Andersen, A. C.: Can the hemoglobin characteristics of vesicomyid clam species influence their distribution in deepsea sulfide-rich sediments? A case study in the Angola Basin, Deep-Sea Res. Pt. II, 142(Supplement C), 219-232, https://doi.org/10.1016/j.dsr2.2016.11.009, 2017.

Degen, R., Jørgensen, L. L., Ljubin, P., Ellingsen, I. H., Pehlke, H., and Brey, T.: Patterns and drivers of megabenthic secondary production on the Barents Sea shelf, J. Mar. Ecol. Prog., 546, 1-16, https://doi.org/10.3354/meps11662, 2016.

Dubilier, N., Bergin, C., and Lott, C.: Symbiotic diversity in marine animals: the art of harnessing chemosynthesis, Nat. Rev. Microbiol., 6, 725-740, https://doi.org/10.1038/nrmicro1992, 2008.

Fisher, C. R.: Chemoautotrophic and methanotrophic symbioses in marine invertebrates, Rev. Aquat. Sci., 2, 399-436, 1990.

Gebruk, A. V., Krylova, E. M., Lein, A. Y., Vinogradov, G. M., Anderson, E., Pimenov, N. V., Cherkashev, G. A., and Crane, K.: Methane seep community of the Håkon Mosby mud volcano (the Norwegian Sea): composition and trophic aspects, Sarsia, 88, 394-403, https://doi.org/10.1080/00364820310003190, 2003. 
Grupe, B. M., Krach, M. L., Pasulka, A. L., Maloney, J. M., Levin, L. A., and Frieder, C. A.: Methane seep ecosystem functions and services from a recently discovered southern California seep, Mar. Ecol., 36, 91-108, https://doi.org/10.1111/maec.12243, 2015.

Hansen, J., Hoff, U., Sztybor, K., and Rasmussen, T. L.: Taxonomy and palaeoecology of two Late Pleistocene species of vesicomyid bivalves from cold methane seeps at Svalbard $\left(79^{\circ} \mathrm{N}\right)$, J. Molluscan Stud., 1-10, https://doi.org/10.1093/mollus/eyx014, 2017.

Haug, T., Bogstad, B., Chierici, M., Gjøsæter, H., Hallfredsson, E. H., Høines, Å. S., Hoel, A. H., Ingvaldsen, R. B., Jørgensen, L. L., Knutsen, T., Loeng, H., Naustvoll, L.-J., Røttingen, I., and Sunnanå, K.: Future harvest of living resources in the Arctic Ocean north of the Nordic and Barents Seas: A review of possibilities and constraints, Fish. Res., 188(Supplement C), 38-57, https://doi.org/10.1016/j.fishres.2016.12.002, 2017.

Hayward, P. J. and Ryland, J. S.: Handbook of the Marine Fauna of North-West Europe, OUP Oxford, Oxford, England, 1995.

Hessler, R. R., Smithey, W. M., Boudrias, M. A., Keller, C. H., Lutz, R. A., and Childress, J. J.: Temporal change in megafauna at the Rose Garden hydrothermal vent (Galapagos Rift; Eastern tropical Pacific), Deep-Sea Res. Pt. I, 35, 1681-1709, 1988.

Higgs, N. D., Newton, J., and Attrill, M. J.: Caribbean Spiny Lobster Fishery Is Underpinned by Trophic Subsidies from Chemosynthetic Primary Production, Curr. Biol., 26, 3393-3398, https://doi.org/10.1016/j.cub.2016.10.034, 2016.

Hilário, A., Capa, M., Dahlgren, T. G., Halanych, K. M., Little, C. T. S., Thornhill, D. J., Verna, C., and Glover, A. G.: New perspectives on the ecology and evolution of siboglinid tubeworms, PloS One, 6, e16309, https://doi.org/10.1371/journal.pone.0016309, 2011.

Hong, W.-L., Torres, M. E., Kim, J.-H., Choi, J., and Bahk, J.-J.: Towards quantifying the reaction network around the sulfate-methane-transition-zone in the Ulleung Basin, East Sea, with a kinetic modeling approach, Geochim. Cosmochim. Acta, 140(Supplement C), 127-141, https://doi.org/10.1016/j.gca.2014.05.032, 2014

Hong, W.-L., Torres, M. E., Carroll, J., Crémière, A., Panieri, G., Yao, H., and Serov, P.: Seepage from an arctic shallow marine gas hydrate reservoir is insensitive to momentary ocean warming, Nat. Commun., 8, 15745, https://doi.org/10.1038/ncomms15745, 2017.

Hong, W.-L., Torres, M. E., Portnov, A., Waage, M., Haley, B., and Lepland, A.: Variations in Gas and Water Pulses at an Arctic Seep: Fluid Sources and Methane Transport, Geophys. Res. Lett., 2018, https://doi.org/10.1029/2018GL077309, 2018.

Hovland, M. and Svensen, H.: Submarine pingoes: Indicators of shallow gas hydrates in a pockmark at Nyegga, Norwegian Sea, Mar. Geol., 228, 15-23, https://doi.org/10.1016/j.margeo.2005.12.005, 2006.

Ingvaldsen, R. B. and Loeng, H.: Physical Oceanography, in Ecosystem Barents Sea, edited by: Sakshaug, E., Johnsen, G. H., and Kovacs, K. M., 33-64, Tapir Academic Press, Trondheim, 2009.

Johannesen, E., Ingvaldsen, R. B., Bogstad, B., Dalpadado, P., Eriksen, E., Gjøsæter, H., Knutsen, T., Skern-Mauritzen, M., and Stiansen, J. E.: Changes in Barents Sea ecosystem state, 1970-2009: climate fluctuations, human impact, and trophic interactions, ICES J. Mar. Sci., 69, 880-889, https://doi.org/10.1093/icesjms/fss046, 2012.

Jørgensen, L. L., Ljubin, P., Skjoldal, H. R., Ingvaldsen, R. B., Anisimova, N., and Manushin, I.: Distribution of benthic megafauna in the Barents Sea: baseline for an ecosystem approach to management, ICES J. Mar. Sci., 72, 595-613, https://doi.org/10.1093/icesjms/fsu106, 2015.

Kim, B., Rachor, E., Sirenko, B. I., Aplonov, V., Starobogatov, Y., and Stein, R.: Thermal discharge points on the Gakkel Ridge (Arctic Basin), Explor. Faunas Seas, 56, 5-14, 2006.

Knittel, K. and Boetius, A.: Anaerobic oxidation of methane: progress with an unknown process, Annu. Rev. Microbiol., 63, 311-334, https://doi.org/10.1146/annurev.micro.61.080706.093130, 2009.

Knittel, K., Lösekann, T., Boetius, A., Kort, R., and Amann, R.: Diversity and Distribution of Methanotrophic Archaea at Cold Seeps, Appl. Environ. Microbiol., 71, 467-479, https://doi.org/10.1128/AEM.71.1.467-479.2005, 2005.

Kolb, B. and Ettre, L. S.: Static Headspace-Gas Chromatography: Theory and Practice, John Wiley \& Sons, Hoboken, New Jersey, USA, 2006.

Krylova, E. M., Gebruk, A. V., Portnova, D. A., Todt, C. and Haflidason, H.: New species of the genus Isorropodon (Bivalvia: Vesicomyidae: Pliocardiinae) from cold methane seeps at Nyegga (Norwegian Sea, Vøring Plateau, Storrega Slide), J. Mar. Biol. Assoc. UK, 91, 1135-1144, https://doi.org/10.1017/S002531541100004X, 2011.

Kuzmin, C. A., Akhtarin, S. M., and Menis, D. T.: First findings of snow crab Chionoecetes opilio (Fabricus) (Decapods: Majidae) in the Barents Sea, Zool. J., 77, 489-491, 1998.

Kuzmin, C. A., Akhtarin, S. M., and Menis, D. T.: The first finding of snow crab Chionoecetes opilio (Fabricus) (Decapoda: Majidae) in the Barents Sea, Can. Transl. Fish Aquat. Sci., 5667, 1-5, 1999.

Lessard-Pilon, S., Porter, M. D., Cordes, E. E., MacDonald, I., and Fisher, C. R.: Community composition and temporal change at deep Gulf of Mexico cold seeps, Deep-Sea Res. Pt. II, 57, 18911903, https://doi.org/10.1016/j.dsr2.2010.05.012, 2010.

Levin, L. A.: Ecology of cold seep sediments: interactions of fauna with flow, chemistry and microbes, Oceanogr. Mar. Biol. Annu. Rev., 43, 1-46, 2005.

Levin, L. A., Ziebis, W., Mendoza, G. F., Growney-Cannon, V., and Walther, S.: Recruitment response of methaneseep macrofauna to sulfide-rich sediments: An in situ experiment, J. Exp. Mar. Biol. Ecol., 330, 132-150, https://doi.org/10.1016/j.jembe.2005.12.022, 2006.

Levin, L. A., Mendoza, G. F., Grupe, B. M., Gonzalez, J. P., Jellison, B., Rouse, G., Thurber, A. R., and Waren, A.: Biodiversity on the Rocks: Macrofauna Inhabiting Authigenic Carbonate at Costa Rica Methane Seeps, PLoS ONE, 10, https://doi.org/10.1371/journal.pone.0131080, 2015.

Levin, L. A., Baco, A. R., Bowden, D. A., Colaco, A., Cordes, E. E., Cunha, M. R., Demopoulos, A. W. J., Gobin, J., Grupe, B. M., Le, J., Metaxas, A., Netburn, A. N., Rouse, G. W., Thurber, A. R., Tunnicliffe, V., Van Dover, C. L., Vanreusel, A., and Watling, L.: Hydrothermal vents and methane seeps: rethinking the sphere of influence, Front. Mar. Sci., 3, 72, https://doi.org/10.3389/fmars.2016.00072, 2016. 
Littman, R. A., Willis, B. L., Pfeffer, C., and Bourne, D. G.: Diversities of coral-associated bacteria differ with location, but not species, for three acroporid corals on the Great Barrier Reef, FEMS Microbiol. Ecol., 68, 152-163, https://doi.org/10.1111/j.1574-6941.2009.00666.x, 2009.

Lösekann, T., Knittel, K., Nadalig, T., Fuchs, B., Niemann, H., Boetius, A., and Amann, R.: Diversity and Abundance of Aerobic and Anaerobic Methane Oxidizers at the Haakon Mosby Mud Volcano, Barents Sea, Appl. Environ. Microbiol., 73, 33483362, https://doi.org/10.1128/AEM.00016-07, 2007.

Lösekann, T., Robador, A., Niemann, H., Knittel, K., Boetius, A., and Dubilier, N.: Endosymbioses between bacteria and deep-sea siboglinid tubeworms from an Arctic Cold Seep (Haakon Mosby Mud Volcano, Barents Sea), Environ. Microbiol., 10, 3237-3254, https://doi.org/10.1111/j.1462-2920.2008.01712.x, 2008.

Marcon, Y., Sahling, H., Allais, A.-G., Bohrmann, G., and Olu, K.: Distribution and temporal variation of mega-fauna at the Regab pockmark (Northern Congo Fan), based on a comparison of videomosaics and geographic information systems analyses, Mar. Ecol., 35, 77-95, https://doi.org/10.1111/maec.12056, 2014.

Martin, J. W. and Haney, T. A.: Decapod crustaceans from hydrothermal vents and cold seeps: a review through 2005, Zool. J. Linn. Soc., 145, 445-522, https://doi.org/10.1111/j.10963642.2005.00178.x, 2005.

Masuzawa, T., Handa, N., Kitagawa, H., and Kusakabe, M.: Sulfate reduction using methane in sediments beneath a bathyal "cold seep" giant clam community off Hatsushima Island, Sagami Bay, Japan, Earth Planet. Sc. Lett., 110, 39-50, https://doi.org/10.1016/0012-821X(92)90037-V, 1992.

Meunier, C., Andersen, A. C., Bruneaux, M., Le Guen, D., Terrier, P., Leize-Wagner, E., and Zal, F.: Structural characterization of hemoglobins from Monilifera and Frenulata tubeworms (Siboglinids): First discovery of giant hexagonalbilayer hemoglobin in the former "Pogonophora" group, Comp. Biochem. Physiol. A. Mol. Integr. Physiol., 155, 41-48, https://doi.org/10.1016/j.cbpa.2009.09.010, 2010.

Meyer, K. S., Wagner, J. K. S., Ball, B., Turner, P. J., Young, C. M., and Van Dover, C. L.: Hyalinoecia artifex: Field notes on a charismatic and abundant epifaunal polychaete on the US Atlantic continental margin, Invertebr. Biol., 135, 211-224, https://doi.org/10.1111/ivb.12132, 2016.

Myers, N., Mittermeier, R. A., Mittermeier, C. G., da Fonseca, G. A. B., and Kent, J.: Biodiversity hotspots for conservation priorities, Nature, 403, 853-858, https://doi.org/10.1038/35002501, 2000.

Niemann, H., Lösekann, T., de Beer, D., Elvert, M., Nadalig, T., Knittel, K., Amann, R., Sauter, E. J., Schlüter, M., Klages, M., Foucher, J. P., and Boetius, A.: Novel microbial communities of the Haakon Mosby mud volcano and their role as a methane sink, Nature, 443, 854-858, https://doi.org/10.1038/nature05227, 2006.

Niemann, H., Linke, P., Knittel, K., MacPherson, E., Boetius, A., Brückmann, W., Larvik, G., Wallmann, K., Schacht, U., Omoregie, E., Hilton, D., Brown, K., and Rehder, G.: MethaneCarbon Flow into the Benthic Food Web at Cold Seeps - A Case Study from the Costa Rica Subduction Zone, PloS One, 8, e74894, https://doi.org/10.1371/journal.pone.0074894, 2013.

Norwegian Directorate of Fisheries: Economic and biological figures from Norwegian fisheries, available at:
http://www.fiskeridir.no/Yrkesfiske/Statistikkyrkesfiske/ Statistiske-publikasjoner/Noekkeltall-for-de-norskefiskeriene, last access: 12 December 2017.

Norwegian Ministry of the Environment: First update of the integrated management plan for the marine environment of the Barents Sea-Lofoten area, Report to the Storting (white paper), Norway, available at: https://www.regjeringen.no/ contentassets/db61759a16874cf28b2f074c9191bed8/en-gb/ pdfs/stm201020110010000en_pdfs.pdf (last access: 6 October 2017), 2010.

Olu, K., Caprais, J. C., Galéron, J., Causse, R., von Cosel, R., Budzinski, H., Ménach, K. L., Roux, C. L., Levaché, D., Khripounoff, A., and Sibuet, M.: Influence of seep emission on the non-symbiont-bearing fauna and vagrant species at an active giant pockmark in the Gulf of Guinea (Congo-Angola margin), Deep-Sea Res. Pt. II, 56, 2380-2393, https://doi.org/10.1016/j.dsr2.2009.04.017, 2009.

Onarheim, I. H. and Årthun, M.: Toward an ice-free Barents Sea, Geophys. Res. Lett., 44, 2017GL074304, https://doi.org/10.1002/2017GL074304, 2017.

Panieri, G., Alexandropoulou, N., Bruvik, K., Carrier, V., Dessandier, P. A., Dølven, K. O., Valberg, E., Fornari, D. J., Gründger, F., Kurras, G. J., Yao, H., Holm, T., Lindgren, M., Melaniuk, K., Olsen, B. R., Ofstad, S., Patton, H., Romeyn, R., Sauer, S., Sen, A., and Sert, M. F.: Cruise report CAGE 17-2 AMGG, Cruise report, Centre for Arctic Gas Hydrate, Environment and Climate (CAGE), Troms $\varnothing, 2017$.

Paull, C. K., Hecker, B., Commeau, R., Freeman-Lynde, R. P., Neumann, C., Corso, W. P., Golubic, S., Hook, J. E., Sikes, E., and Curray, J.: Biological communities at the Florida escarpment resemble hydrothermal vent taxa, Science, 226, 965-967, https://doi.org/10.1126/science.226.4677.965, 1984.

Paull, C. K., Ussler, W., Dallimore, S. R., Blasco, S. M., Lorenson, T. D., Melling, H., Medioli, B. E., Nixon, F. M., and McLaughlin, F. A.: Origin of pingo-like features on the Beaufort Sea shelf and their possible relationship to decomposing methane gas hydrates, Geophys. Res. Lett., 34, L01603, https://doi.org/10.1029/2006GL027977, 2007.

Paull, C. K., Dallimore, S. R., Caress, D. W., Gwiazda, R., Melling, H., Riedel, M., Jin, Y. K., Hong, J. K., Kim, Y.-G., Graves, D., Sherman, A., Lundsten, E., Anderson, K., Lundsten, L., Villinger, H., Kopf, A., Johnson, S. B., Hughes Clarke, J., Blasco, S., Conway, K., Neelands, P., Thomas, H., and Côté, M.: Active mud volcanoes on the continental slope of the Canadian Beaufort Sea, Geochem. Geophys. Geosys., 16, 3160-3181, https://doi.org/10.1002/2015GC005928, 2015.

Petersen, C. J., Bünz, S., Hustoft, S., Mienert, J., and Klaeschen, D.: High-resolution P-Cable 3D seismic imaging of gas chimney structures in gas hydrated sediments of an Arctic sediment drift, Mar. Pet. Geol., 27, 1981-1994, https://doi.org/10.1016/j.marpetgeo.2010.06.006, 2010.

Pimenov, N. V., Savvichev, A. S., Rusanov, I. I., Lein, A. Y., and Ivanov, M. V.: Microbiological Processes of the Carbon and Sulfur Cycles at Cold Methane Seeps of the North Atlantic, Microbiology, 69, 709-720, https://doi.org/10.1023/A:1026666527034, 2000.

Pissart, A.: Pingos and palsas: A review of the present state of knowledge, Polar Geogr. Geol., 9, 171-195, https://doi.org/10.1080/10889378509377249, 1985. 
Pizarro, O. and Singh, H.: Toward large-area mosaicking for underwater scientific applications, IEEE J. Ocean. Eng., 28, 651-672, 2003.

Podowski, E. L., Moore, T. S., Zelnio, K. A., Luther, G. W., and Fisher, C. R.: Distribution of diffuse flow megafauna in two sites on the Eastern Lau Spreading Center, Tonga, Deep-Sea Res. Pt. I, 56, 2041-2056, 2009.

Podowski, E. L., Ma, S., Luther III, G. W., Wardrop, D., and Fisher, C. R.: Biotic and abiotic factors affecting distributions of megafauna in diffuse flow on andesite and basalt along the Eastern Lau Spreading Center, Tonga, Mar. Ecol. Prog. Ser., 418, 25-45, 2010.

Portnov, A., Vadakkepuliyambatta, S., Mienert, J., and Hubbard, A.: Ice-sheet-driven methane storage and release in the Arctic, Nat. Commun., 7, 10314, https://doi.org/10.1038/ncomms10314, 2016.

Portnova, D. A., Mokievsky, V. O., Haflidason, H., and Todt, K.: Metazoan meiobenthos and nematode assemblages in the Nyegga Region of methane seepage (Norwegian Sea), Russ. J. Mar. Biol., 40, 255-265, https://doi.org/10.1134/S1063074014040075, 2014.

Rohwer, F., Seguritan, V., Azam, F., and Knowlton, N.: Diversity and distribution of coral-associated bacteria, Mar. Ecol. Prog. Ser., 243, 1-10, 2002.

Rybakova (Goroslavskaya), E., Galkin, S., Bergmann, M., Soltwedel, T., and Gebruk, A.: Density and distribution of megafauna at the Håkon Mosby mud volcano (the Barents Sea) based on image analysis, Biogeosciences, 10, 3359-3374, https://doi.org/10.5194/bg-10-3359-2013, 2013.

Sahling, H., Galkin, S. V., Salyuk, A., Greinert, J., Foerstel, H., Piepenburg, D., and Suess, E.: Depth-related structure and ecological significance of cold-seep communities - a case study from the Sea of Okhotsk, Deep-Sea Res. Pt. I, 50, 1391-1409, https://doi.org/10.1016/j.dsr.2003.08.004, 2003.

Sahling, H., Römer, M., Pape, T., Bergès, B., dos Santos Fereirra, C., Boelmann, J., Geprägs, P., Tomczyk, M., Nowald, N., Dimmler, W., Schroedter, L., Glockzin, M., and Bohrmann, G.: Gas emissions at the continental margin west of Svalbard: mapping, sampling, and quantification, Biogeosciences, 11, 6029-6046, https://doi.org/10.5194/bg-11-6029-2014, 2014.

Sakshaug, E., Johnsen, G., Kristensen, E., von Quildfeldt, C., Rey, F., Slagstad, D., and Thingstad, F.: Phytoplankton and primary production, in: Ecossytem Barents Sea, edited by: Sakshaug, E., Johnsen, G., and Kovacs, K. M., 167-208, Tapir Academic Press, Trondheim, 2009.

Sarrazin, J., Juniper, S. K., Massoth, G., and Legendre, P.: Physical and chemical factors influencing species distributions on hydrothermal sulfide edifices of the Juan de Fuca Ridge, northeast Pacific, Mar. Ecol. Prog. Ser., 190, 89-112, https://doi.org/10.3354/meps190089, 1999.

Seabrook, S., C. De Leo, F., Baumberger, T., Raineault, N., and Thurber, A. R.: Heterogeneity of methane seep biomes in the Northeast Pacific, Deep-Sea Res. Pt. II, 150, 195-209, doi:10.1016/j.dsr2.2017.10.016, 2018.

Sellanes, J., Quiroga, E., and Neira, C.: Megafauna community structure and trophic relationships at the recently discovered Concepción Methane Seep Area, Chile, $\sim 36^{\circ} \mathrm{S}$, ICES J. Mar. Sci., 65, 1102-1111, https://doi.org/10.1093/icesjms/fsn099, 2008.
Sen, A., Becker, E. L., Podowski, E. L., Wickes, L. N., Ma, S., Mullaugh, K. M., Hourdez, S., Luther III, G. W., and Fisher, C. R.: Distribution of mega fauna on sulfide edifices on the Eastern Lau Spreading Center and Valu Fa Ridge, Deep-Sea Res. Pt. I, 72, 48-60, https://doi.org/10.1016/j.dsr.2012.11.003, 2013.

Sen, A., Podowski, E. L., Becker, E. L., Shearer, E. A., Gartman, A., Yücel, M., Hourdez, S., Luther III, G. W., and Fisher, C. R.: Community succession in hydrothermal vent habitats of the Eastern Lau Spreading Center and Valu Fa Ridge, Tonga, Limnol. Oceanogr., 59, 1510-1528, https://doi.org/10.4319/lo.2014.59.5.1510, 2014.

Sen, A., Kim, S., Miller, A. J., Hovey, K. J., Hourdez, S., Luther, G. W., and Fisher, C. R.: Peripheral communities of the Eastern Lau Spreading Center and Valu Fa Ridge: community composition, temporal change and comparison to near-vent communities, Mar. Ecol., 37, 599-617, https://doi.org/10.1111/maec.12313, 2016.

Sen, A., Dennielou, B., Tourolle, J., Arnaubec, A., Rabouille, C., and Olu, K.: Fauna and habitat types driven by turbidity currents in the lobe complex of the Congo deep-sea fan, Deep-Sea Res. Pt. II, 142, 167-179, https://doi.org/10.1016/j.dsr2.2017.05.009, 2017.

Serié, C., Huuse, M., and Schødt, N. H.: Gas hydrate pingoes: Deep seafloor evidence of focused fluid flow on continental margins, Geology, 40, 207-210, https://doi.org/10.1130/G32690.1, 2012.

Serov, P., Vadakkepuliyambatta, S., Mienert, J., Patton, H., Portnov, A., Silyakova, A., Panieri, G., Carroll, M. L., Carroll, J., Andreassen, K., and Hubbard, A.: Postglacial response of Arctic Ocean gas hydrates to climatic amelioration, P. Natl. Acad. Sci. USA, 114, 6215-6220, https://doi.org/10.1073/pnas.1619288114, 2017.

Siboni, N., Ben-Dov, E., Sivan, A., and Kushmaro, A.: Global distribution and diversity of coral-associated Archaea and their possible role in the coral holobiont nitrogen cycle, Environ. Microbiol., 10, 2979-2990, https://doi.org/10.1111/j.14622920.2008.01718.x, 2008.

Sibuet, M. and Olu, K.: Biogeography, biodiversity and fluid dependence of deep-sea cold-seep communities at active and passive margins, Deep-Sea Res. Pt. II, 45, 517-567, https://doi.org/10.1016/S0967-0645(97)00074-X, 1998.

Sibuet, M. and Olu-Le Roy, K.: Cold Seep Communities on Continental Margins: Structure and Quantitative Distribution Relative to Geological and Fluid Venting Patterns, in: Ocean Margin Systems, 235-251, Springer, Berlin, Heidelberg, 2002.

Singh, H., Howland, J., and Pizarro, O.: Advances in large-area photomosaicking underwater, IEEE J. Ocean. Eng., 29, 872-886, https://doi.org/10.1109/JOE.2004.831619, 2004.

Sirenko, B. I., Petryashev, V. V., Rachor, E., and Hinz, K.: Bottom biocoenoses of the Laptev Sea and adjacent areas, Berichte Zur Polarforsch, 176, 211-221, 1995.

Smirnov, R. V.: Two new species of Pogonophora from the Arctic mud volcano off northwestern Norway, Sarsia, 85, 141-150, https://doi.org/10.1080/00364827.2000.10414563, 2000.

Smirnov, R. V.: A revision of the Oligobrachiidae (Annelida: Pogonophora), with notes on the morphology and distribution of Oligobrachia haakonmosbiensis Smirnov, Mar. Biol. Res., 10, 972-982, https://doi.org/10.1080/17451000.2013.872799, 2014.

Southward, A. J. and Southward, E. C.: Observations on the role of dissolved organic compounds in the 
nutrition of benthic invertebrates, Sarsia, 45, 69-96, https://doi.org/10.1080/00364827.1970.10411184, 1970.

Southward, A. J., Southward, E. C., Brattegard, T., and Bakke, T.: Further experiments on the value of dissolved organic matter as food for Siboglinum fiordicum (Pogonophora), J. Mar. Biol. Assoc. UK, 59, 133-148, https://doi.org/10.1017/S0025315400046233, 1979.

Southward, A. J., Southward, E. C., Dando, P. R., Rau, G. H., Felbeck, H., and Flügel, H.: Bacterial symbionts and low $13 \mathrm{C} / 12 \mathrm{C}$ ratios in tissues of Pogonophora indicate unusual nutrition and metabolism, Nature, 293, 616-619, https://doi.org/10.1038/293616a0, 1981.

Southward, E. C.: Bacterial Symbionts in Pogonophora, J. Mar. Biol. Assoc. UK, 62, 889-906, https://doi.org/10.1017/S0025315400044131, 1982.

Southward, E. C.: Development of perviata and vestimentifera (pogonophora), in Reproductive Strategies and Developmental Patterns in Annelids, 185-202, Springer, available at: http:// link.springer.com/chapter/10.1007/978-94-017-2887-4_10 (last access: 12 September 2017), 1999.

Southward, E. C.: Class Pogonophora, in Polychaetes and Allies: The Southern Syntehsis Fauna of Australia, vol. 4A, edited by: Beesley, P. L., Ross, G. L. B., and Glasby, C. J., 331-351, CSIRO Publishing, Melbourne, 2000.

Southward, E. C., Schulze, A., and Gardiner, S. L.: Pogonophora (Annelida): form and function, Hydrobiologia, 535-536, 227$251,2005$.

Steenstrup, E. and Tendal, O. S.: The genus Thenea (Porifera, Demospongia, Choristida) in the Norwegian sea and adjacent waters; an annotated key, Sarsia, 67, 259-268, https://doi.org/10.1080/00364827.1982.10421340, 1982.

Suess, E. and Whiticar, M. J.: Methane-derived $\mathrm{CO}_{2}$ in pore fluids expelled from the Oregon subduction zone, Palaeogeogr. Palaeoclimatol. Palaeoecol., 71, 119-136, https://doi.org/10.1016/0031-0182(89)90033-3, 1989.

Sztybor, K. and Rasmussen, T. L.: Diagenetic disturbances of marine sedimentary records from methane-influenced environments in the Fram Strait as indications of variation in seep intensity during the last 35000 years, Boreas, 46, 212-228, https://doi.org/10.1111/bor.12202, 2017.

Tamelander, T., Renaud, P. E., Hop, H., Carroll Jr., M. L., Ambrose Jr., W. G., and Hobson, K. A.: Trophic relationships and pelagic-benthic coupling during summer in the Barents Sea Marginal Ice Zone, revealed by stable carbon and nitrogen isotope measurements, Mar. Ecol. Prog. Ser., 310, 33-46, https://doi.org/10.3354/meps310033, 2006.
Thurber, A. R., Kröger, K., Neira, C., Wiklund, H., and Levin, L. A.: Stable isotope signatures and methane use by New Zealand cold seep benthos, Mar. Geol., 272, 260-269, https://doi.org/10.1016/j.margeo.2009.06.001, 2010.

Urcuyo, I. A., Massoth, G. J., Julian, D., and Fisher, C. R.: Habitat, growth and physiological ecology of a basaltic community of Ridgeia piscesae from the Juan de Fuca Ridge, Deep-Sea Res. Pt. I, 50, 763-780, https://doi.org/10.1016/S0967-0637(03)00061X, 2003.

Vacelet, J. and Donadey, C.: Electron microscope study of the association between some sponges and bacteria, J. Exp. Mar. Biol. Ecol., 30, 301-314, https://doi.org/10.1016/00220981(77)90038-7, 1977.

Vadakkepuliyambatta, S.: Sub-seabed fluid-flow systems and gas hydrates of the SW Barents Sea and North Sea margins, available at: http://munin.uit.no/handle/10037/6198 (last access: 15 January 2016), 2014.

Valentine, D. L.: Emerging Topics in Marine Methane Biogeochemistry, Annu. Rev. Mar. Sci., 3, 147-171, https://doi.org/10.1146/annurev-marine-120709-142734, 2011.

Wallmann, K., Aloisi, G., Haeckel, M., Obzhirov, A., Pavlova, G., and Tishchenko, P.: Kinetics of organic matter degradation, microbial methane generation, and gas hydrate formation in anoxic marine sediments, Geochim. Cosmochim. Acta, 70, 3905-3927, https://doi.org/10.1016/j.gca.2006.06.003, 2006.

Wassmann, P., Duarte, C. M., Agustí, S., and Sejr, M. K.: Footprints of climate change in the Arctic marine ecosystem, Glob. Change Biol., 17, 1235-1249, https://doi.org/10.1111/j.13652486.2010.02311.x, 2011.

Wegley, L., Yu, Y., Breitbart, M., Casas, V., Kline, D. I., and Rohwer, F.: Coral-associated Archaea, Mar. Ecol. Prog. Ser., 273, 89-96, 2004.

Węsławski, J. M., Kendall, M. A., Włodarska-Kowalczuk, M., Iken, K., Kędra, M., Legezynska, J., and Sejr, M. K.: Climate change effects on Arctic fjord and coastal macrobenthic diversity - observations and predictions, Mar. Biodivers., 41, 71-85, https://doi.org/10.1007/s12526-010-0073-9, 2011.

Westbrook, G. K., Thatcher, K. E., Rohling, E. J., Piotrowski, A. M., Pälike, H., Osborne, A. H., Nisbet, E. G., Minshull, T. A., Lanoisellé, M., James, R. H., Hühnerbach, V., Green, D., Fisher, R. E., Crocker, A. J., Chabert, A., Bolton, C., Beszczynska-Möller, A., Berndt, C., and Aquilina, A.: Escape of methane gas from the seabed along the West Spitsbergen continental margin, Geophys. Res. Lett., 36, L15608, https://doi.org/10.1029/2009GL039191, 2009. 